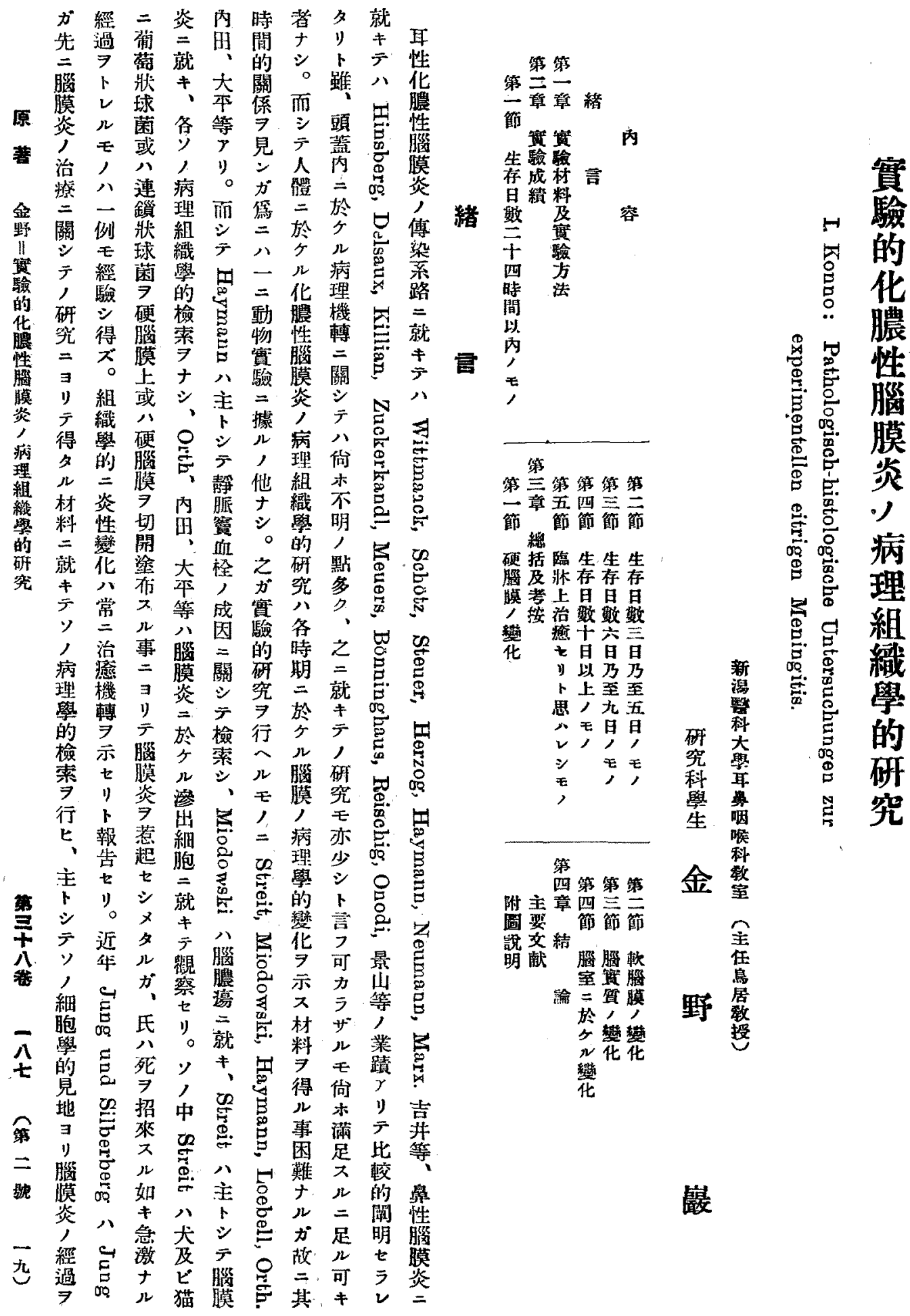




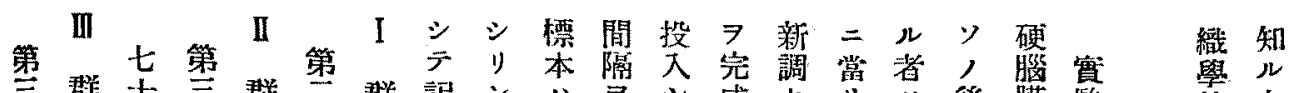

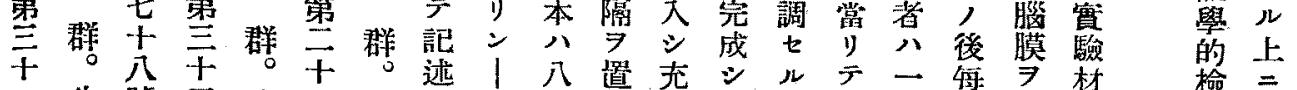
士生號声生

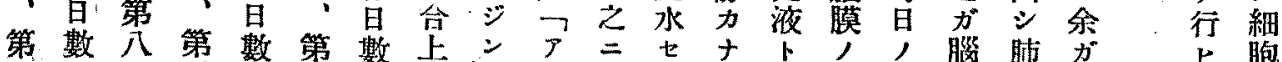

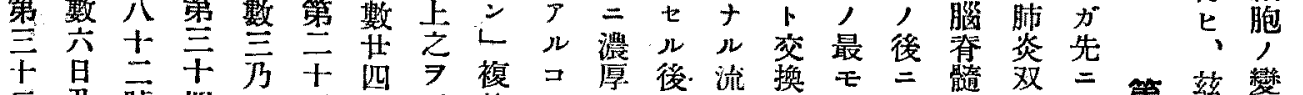

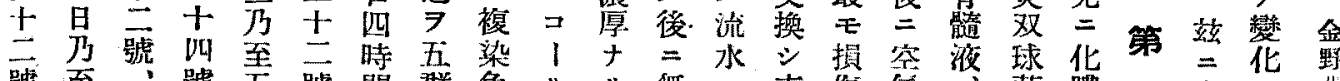

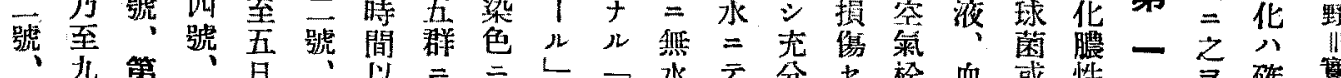
第百第第，第众分

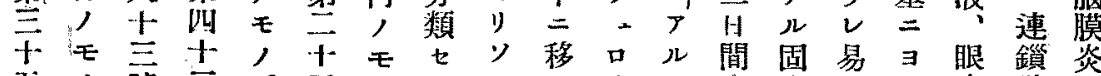

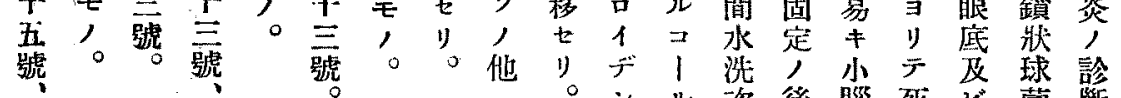

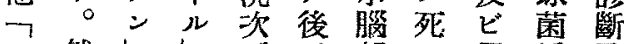

第

第

DI

號

第

四

$1+\frac{1}{1-12}$

號: 呬

第

[1]

$\pm$

第

四

$+$

吾虎

第

第

第

六

號

第

第

交

交虎

第

t

四

躆

第

七

苪

第

景

第

人 然ᄂᄂ

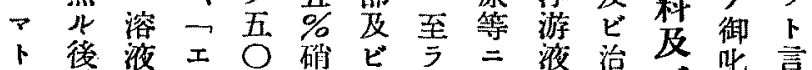

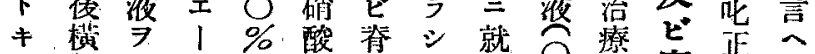

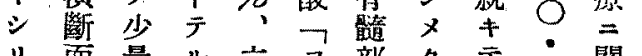

り面量儿六フ部夕爷

$\dot{*}=$ 㱜L

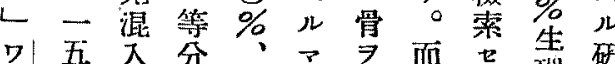

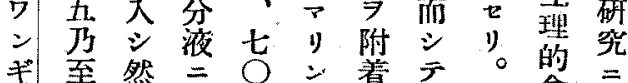

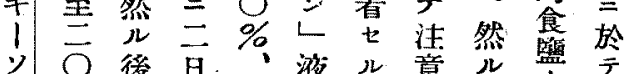

シ $\bigcirc$ 後旦

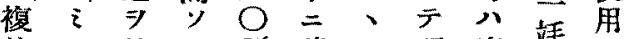

染徐, \% 移一頭家蚝女

色口今後、叶 蓋鬼五心

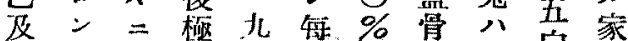

ビレ乾メ○旦つ壁

唫, 燥

章 報、定

告 的

實竞

大 $\Rightarrow$

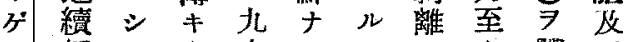

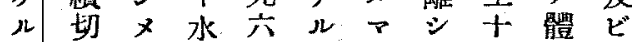

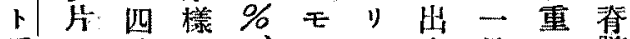

氏 $\Rightarrow$ 乃、, ン来 日一髓

鐵作至 $千$ 热卜七得。

ᄀ製 五 水交液 $シ=-$

人七润口马換三限テ就部

$\checkmark$ 》間 イ

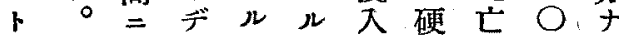

キ染テンココ・シ腦シ・り

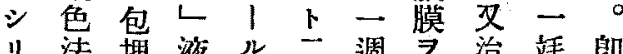

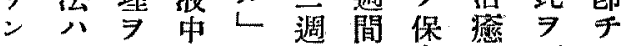

ᄂ 主終 二, 顶, 存七硬頭

染卜儿移順至間シリ腦莣

色シ。シ序三隔得卜膜骨

$=$ テ包一二週 $\Rightarrow$ 思壁

$\exists \neg$ 埋

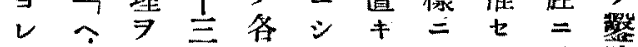

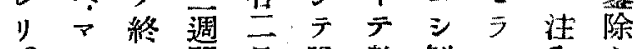

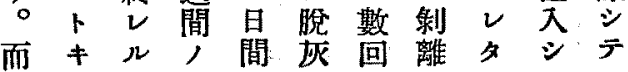

而 $\neq$ ル

驗 仰

方 $力^{\circ}$ 余 的

法之公研

ᄌ $=$

化

情

㶼

J

滋

及

治

療

關

研意

究

行

ᄂ

ガ 第

次 二

竝

病

組 


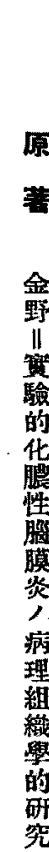

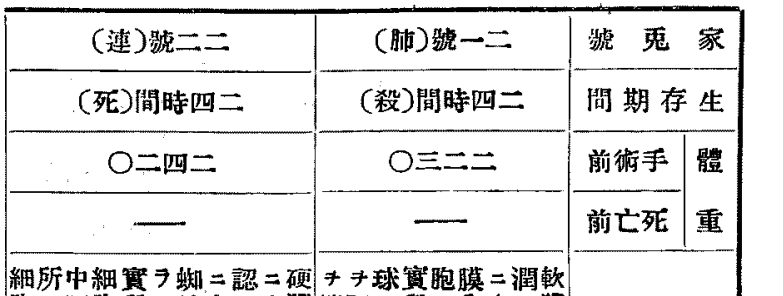

第

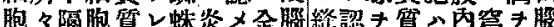

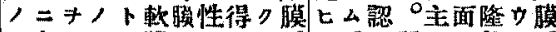

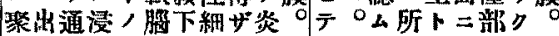

落血汇潤境脱挖胞ル性一多倾○々シ於及'充

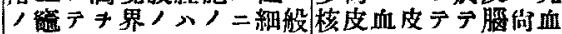

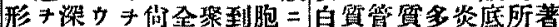

沿認部見保り落レキ著血二周時核性新々明

女 $x$ 二更儿持堙キ心以シ球於問二白細二肥二

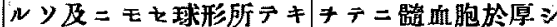

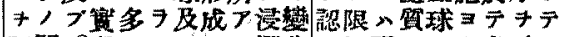

認間○留クルピり減化么周明モョり炎示且

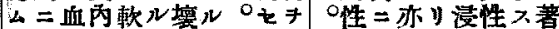

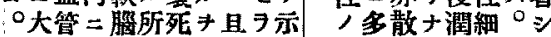

小周㳂膜、物見硬レシ

種葍润

々ノ又著二以 0 膜y,

ナ浸○ショテ內, 內

润尚 $\neq$ 人充 組橉外

炎著軟炎宽满 織造面

性明膜性筫七，中共

メデそ細ノレ暗小

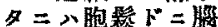

り波小八踈モ比部

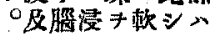

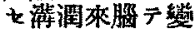

$n, \gamma=$ 膜輯化

*スり炎組度大

認心゙，性䋘然膊

入塞認炎八程小

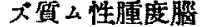

$0^{\circ}=$ o 細脤二部

八胞及シ?

著フビテ路

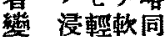

* 潤度臊

認 ギ膜

笋

八 y胞自充 $习$ 硬

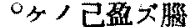

テ著著。㷬

肥シ所明臊緬

厚キ々且膜化

浸炎篮著

居潤性軟舘

レキ組膜, 力

胞八第浸明第㒋

; 又四潤ナ三腽

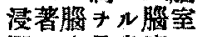

洞空見资空、

キキール性二著

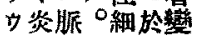

性絡 胞テナ

細溒人著シ
出核在儿七胞蜘 キ

血白性 ${ }^{\circ} \ni$ 充蛛炎

$\neq$ 血, $心$ 满膜性

見救多㕸下种

, / 核 焱且胵胞

游白性硬 八

間出血 絧滕特浸

\section{珙} 罂 輕來膜部颚

度 $シ 心=$ 部

著, 且組比

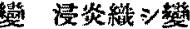

F、潤性/宁化

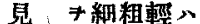
プ、見胞称庭大

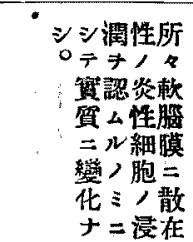

大

腾

部

小

渴

in

捽

幹

部

\begin{tabular}{|c|c|}
\hline 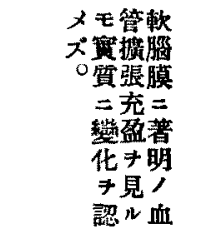 & $\begin{array}{l}\text { 拝 } \\
\text { 顝 } \\
\text { 部 }\end{array}$ \\
\hline 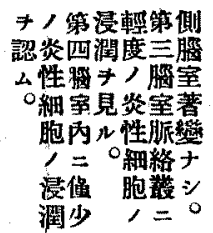 & 得 \\
\hline
\end{tabular}

表

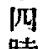

間

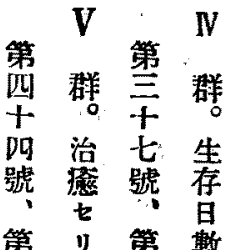

第士思士是

十思言十

一 章

篩

算

第交第夜

十定的。言王

生䨘北

昆虎。

存 㯺

星第 第

嘍 成 $\begin{array}{cc}t \\ t \\ \text { 號 }\end{array}$

叫 績

時

間

以

內

E

號

第

㐊 


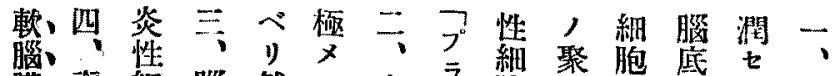

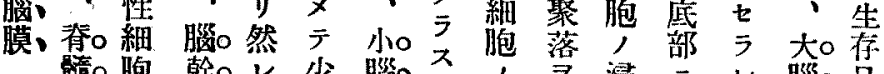
镇。胞 翰。 $v$ 少腦。

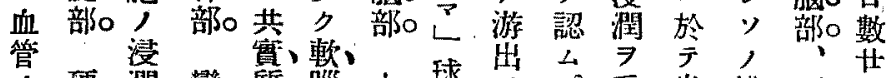

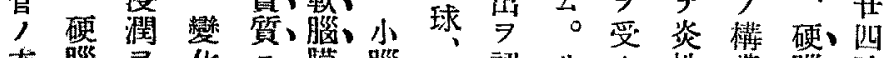
充胋 $\rightarrow$ 化二膜、腦 血膜認, 心ハ部

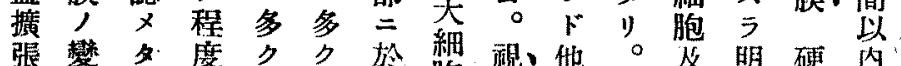

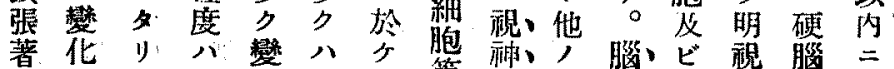

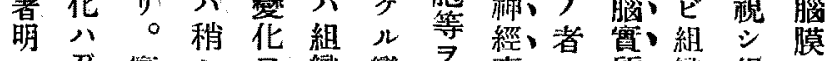

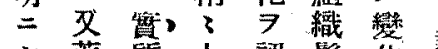
シ著筫、小認铲华

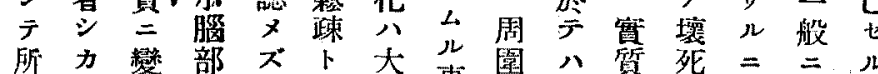

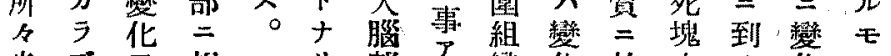

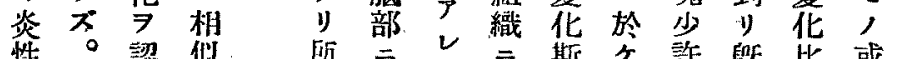

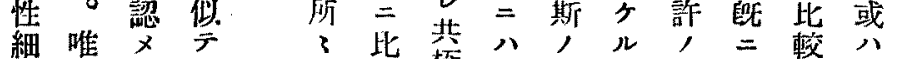
胞第 $x$ 碳、炎 西 澴

性 槙

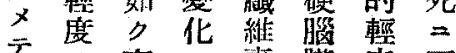
少向八素膜度至

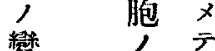
炎度第

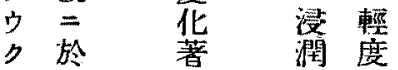

ク於著潤度

硬吕舜少。

膜弪而硬、

多面軟、妾暚、

竞 盟、

䁸莫、

颀

聚, 华尚

实

認

$x$

s

蜊

蛛、明

性 $=$ 无部儿

細 非上雴二モ

胞 ス

淁

潤於認炎

7 名的

リ多最。細モ就

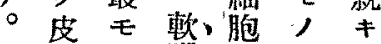

上䈏著腦、

, 八

樂樂

血菅著

官管

充 $\quad+$

血 ル 散

擴者 在

㯑踷

然 三 小管

腔、

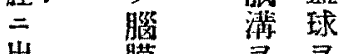

出䏺莫涌

血息蓪訜

見公兵

所 小简

千名晙所

$>$ 萌

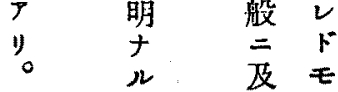

記 丙 明 瞙、笪 於

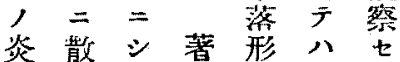

性在

細 性赛

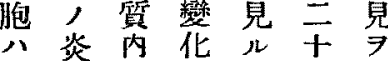

主性 嚓八モ二

卜細縁血, 號

シ胞部管

テ $\Rightarrow$

核公于張蜘、面

白ルル范跦、韭

血, H 充 膜、

球 $i$ 血 血下炎

$\exists$ 份 7 二腔、些

リ木認 シ八組

成 血 $メ$ テ 特 胞

几管 尚 $=$

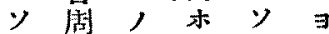

, 圍閪著, 少

他 = = 明 穹

全

般 $v$ 淋多性儿部

巴數 編 炎 及

球炎胞性 ビ 浸 


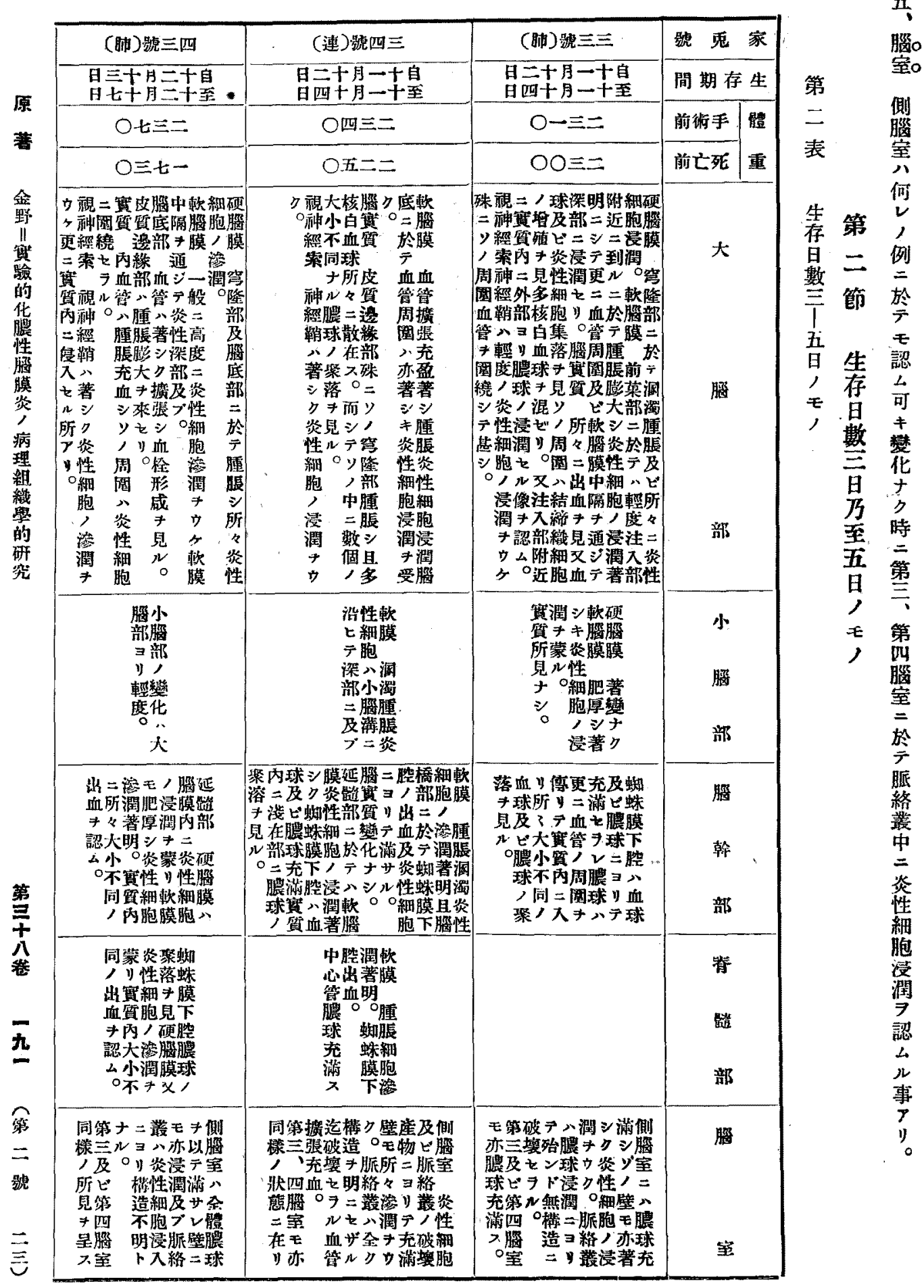




\begin{tabular}{|c|c|c|c|c|c|c|}
\hline \multirow{4}{*}{$\begin{array}{l}\text { 一昌 } \\
\text { 一至 }\end{array}$} & \multirow{2}{*}{$\begin{array}{l}\text { (連)號六六 } \\
\text { 日三月一自 } \\
\text { 日七月一至 }\end{array}$} & \multirow{2}{*}{$\begin{array}{c}\text { (連)號四六 } \\
\begin{array}{c}\text { 日一百一自 } \\
\text { 日西月一至 }\end{array} \\
\end{array}$} & \multirow{2}{*}{$\begin{array}{l}\text { (肺)號三六 } \\
\text { 日一月一自 } \\
\text { 日四月一至 } \\
\end{array}$} & \multirow{2}{*}{$\begin{array}{c}\text { 號二六 } \\
\text { 日一月一皇 } \\
\text { 日四月一至 }\end{array}$} & \multicolumn{2}{|c|}{ 號番鬼家 } \\
\hline & & & & & 問期存 & f生 \\
\hline & O五八二 & O六三二 & O四八二 & O二五二 & 前術手 & 體 \\
\hline & 00四二 & O七九一 & O四三二 & ○七二二 & 前亡死 & 重 \\
\hline 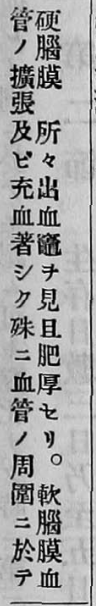 & 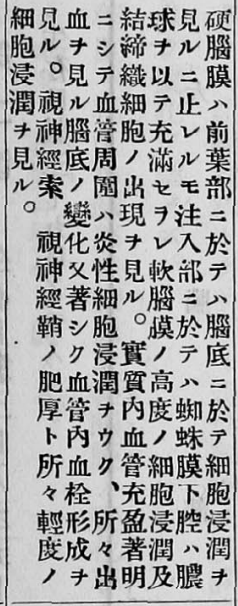 & 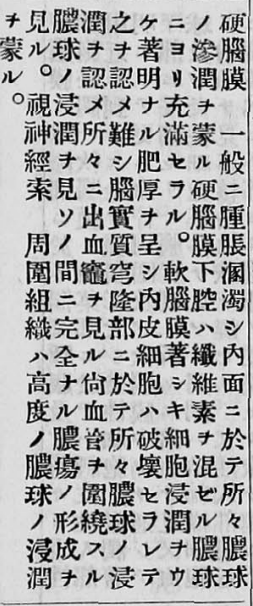 & 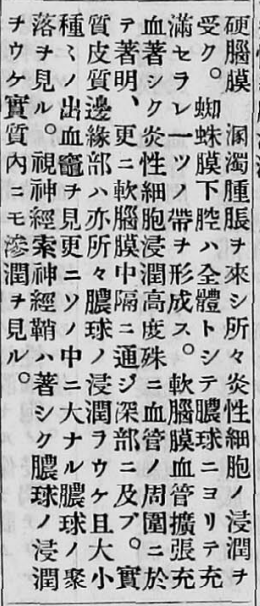 & 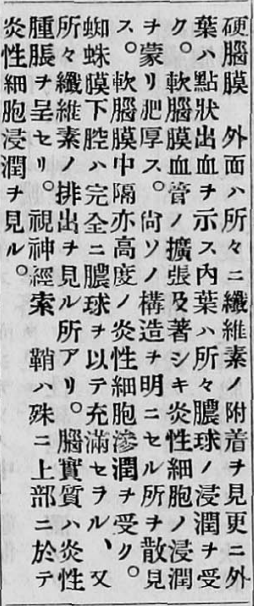 & 部 & \\
\hline 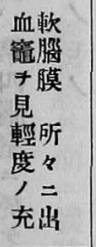 & 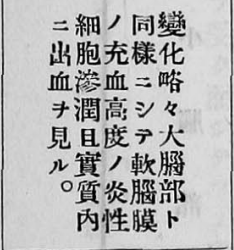 & 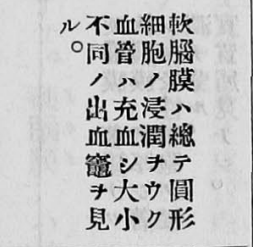 & 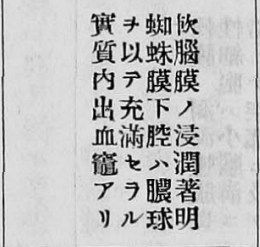 & 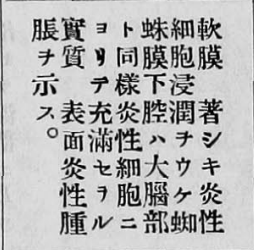 & 部 & \\
\hline 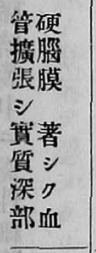 & 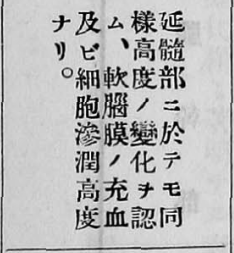 & 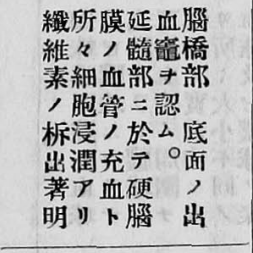 & 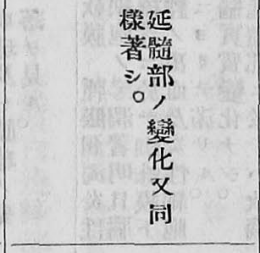 & 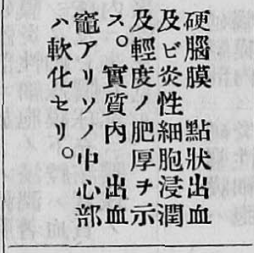 & 膯 & \\
\hline & Sic & & $\sqrt{1029}$ & at & $\begin{array}{l}\text { 脊 } \\
\text { 髄 } \\
\text { 部 }\end{array}$ & \\
\hline 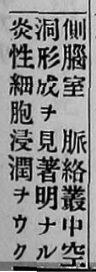 & 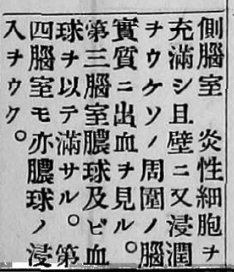 & 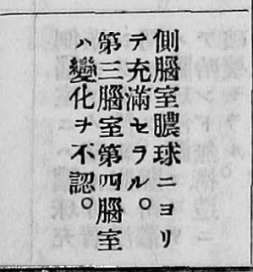 & 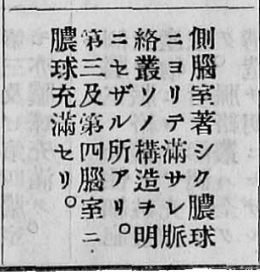 & 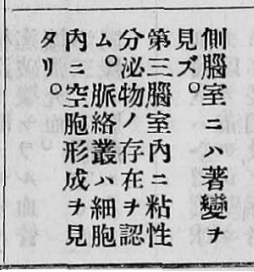 & 室 & \\
\hline
\end{tabular}




\begin{tabular}{|c|c|c|c|c|c|}
\hline 號三八 & 躆三八 & 淲入七 & 学六七 & 號五七 & 跟匹 \\
\hline $\begin{array}{l}\text { 日四壮月一自 } \\
\text { 日公室 } \\
\end{array}$ & $\begin{array}{l}\text { 日亖出一自 } \\
\text { 日五世月一至 }\end{array}$ & $\begin{array}{l}\text { 日九十月一自 } \\
\text { 日至月月一至 }\end{array}$ & 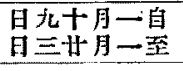 & $\begin{array}{l}\text { 日六士月一自 } \\
\text { 日十三日态 }\end{array}$ & $\begin{array}{l}\text { 日六士月 } \\
\text { 日十三旦 } \\
\end{array}$ \\
\hline $0=-=$ & ○九五二 & $\mathrm{OO}=$ & $O=-二$ & $\mathrm{O} t 二=$ & $\mathrm{O}$ 四O二 \\
\hline ○六九一 & ○八三二 & Ott- & O四七一 & $00-=$ & OO五一 \\
\hline 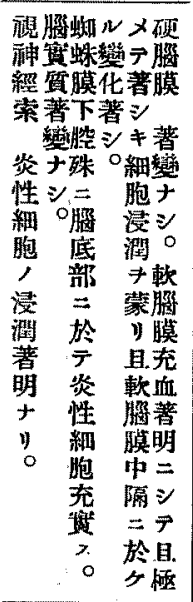 & \multirow{2}{*}{ 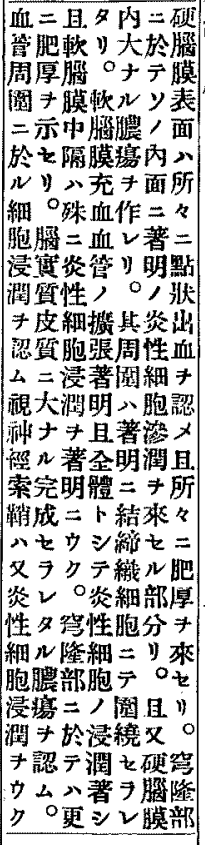 } & 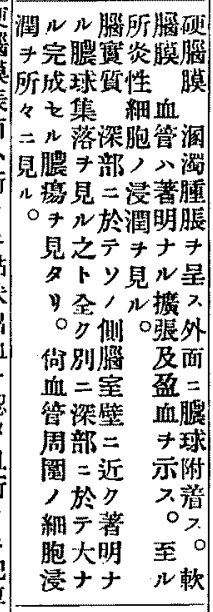 & 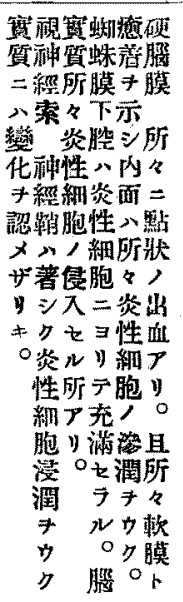 & 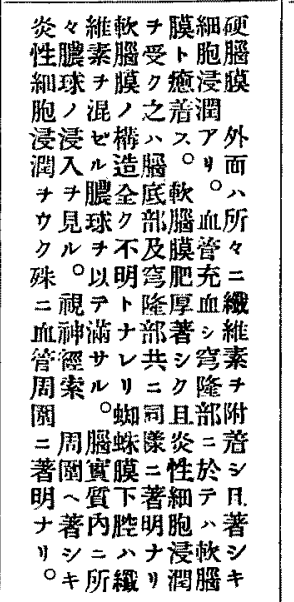 & 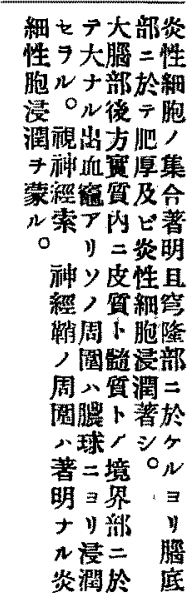 \\
\hline 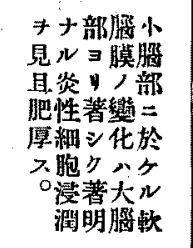 & & 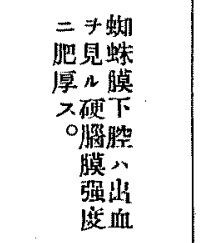 & 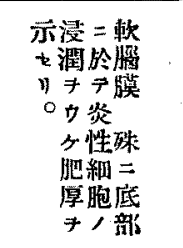 & 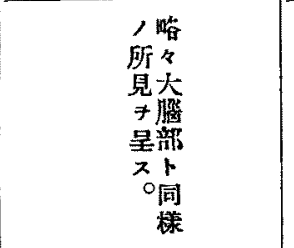 & 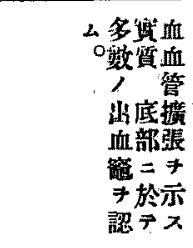 \\
\hline \multirow[t]{2}{*}{ 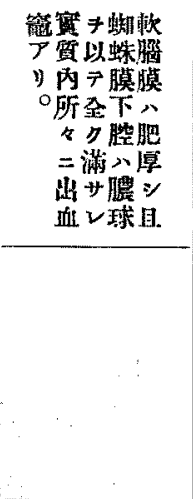 } & 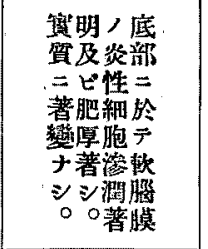 & \multirow[t]{2}{*}{ 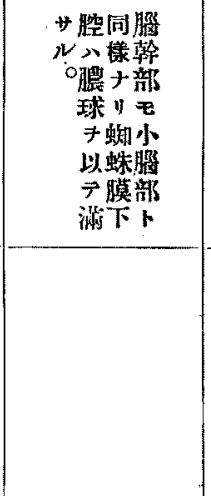 } & 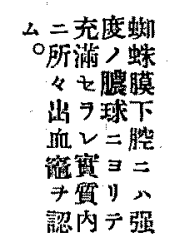 & 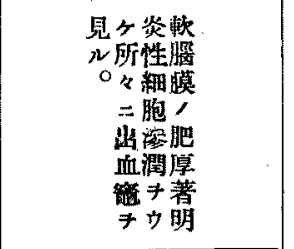 & 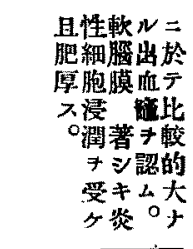 \\
\hline & 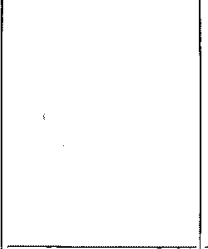 & & 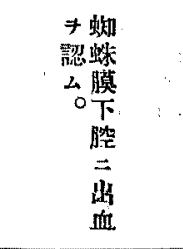 & & \\
\hline 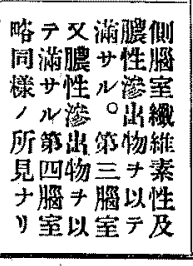 & 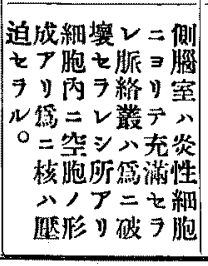 & 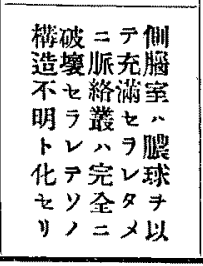 & 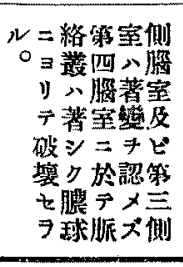 & 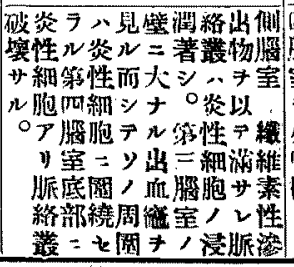 & 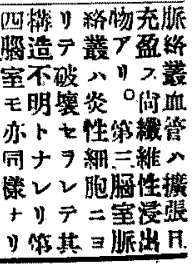 \\
\hline
\end{tabular}




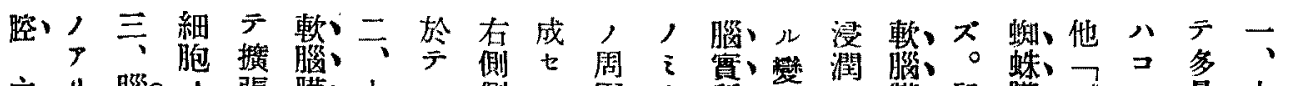

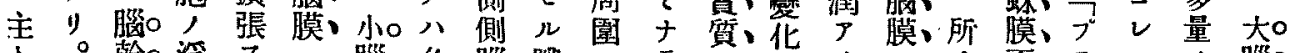
卜 翰o 滛

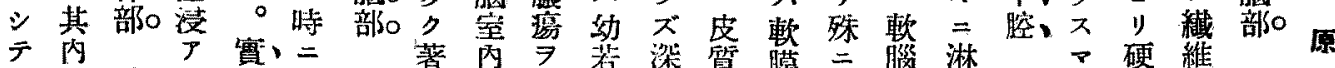

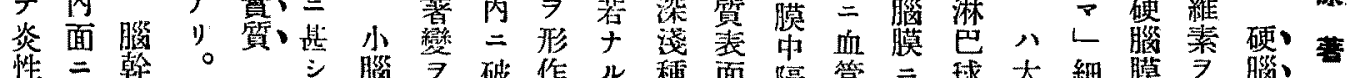

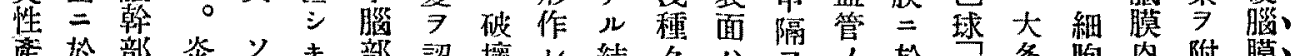

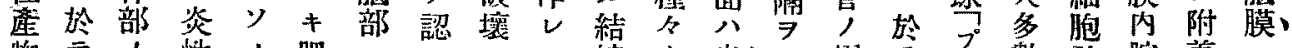

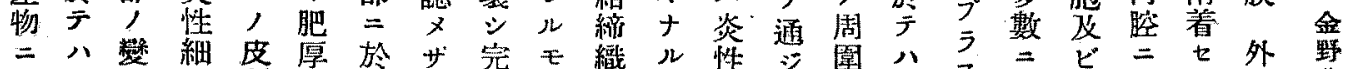

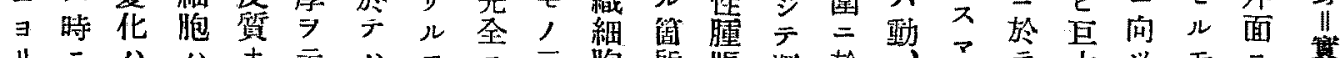

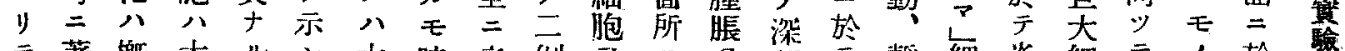

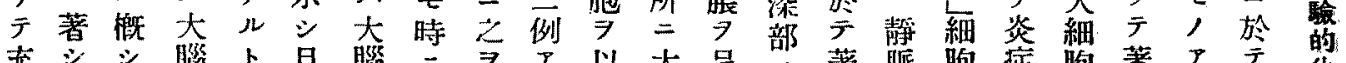

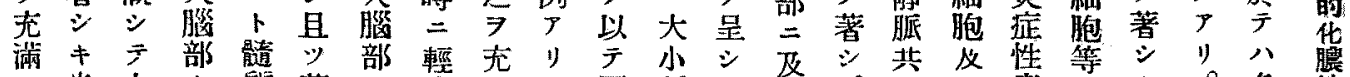

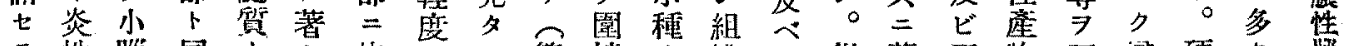

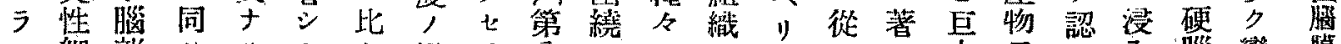
ル細部

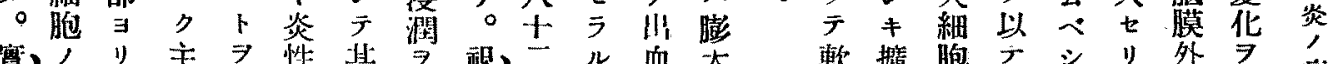

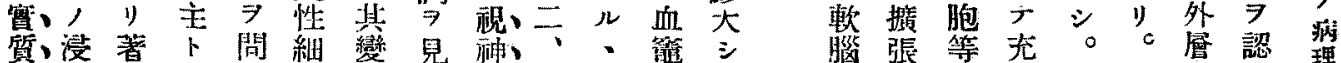
質、㴆著

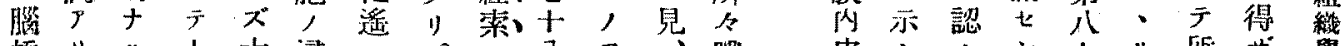

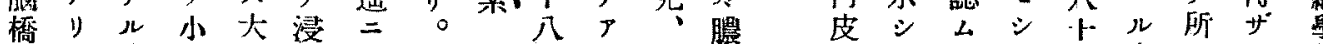

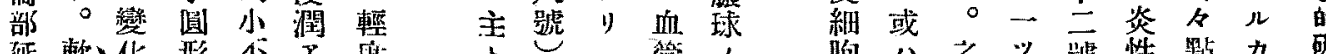

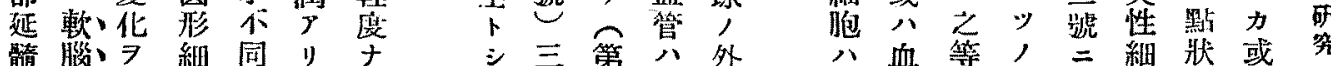

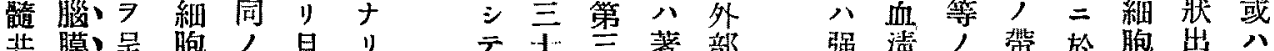
共膜、呈 胞 出

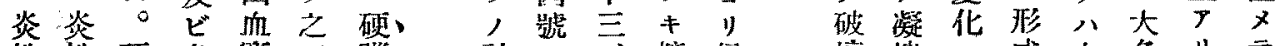

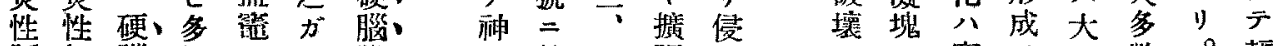

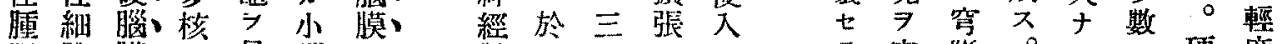

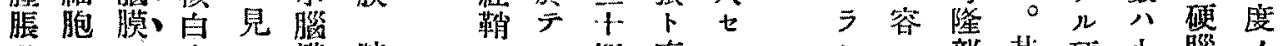

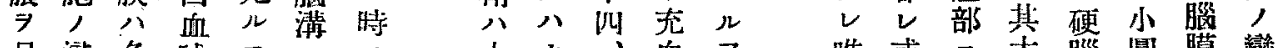
呈掂多球も

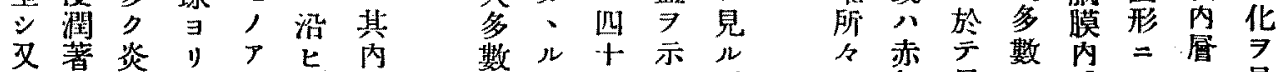

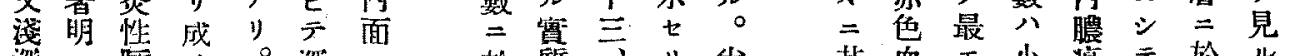

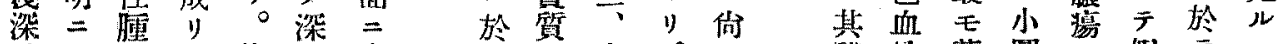

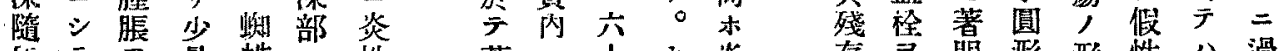

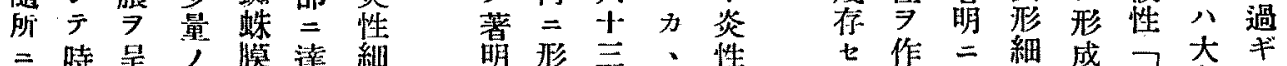

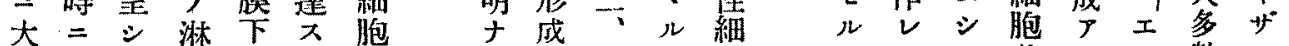

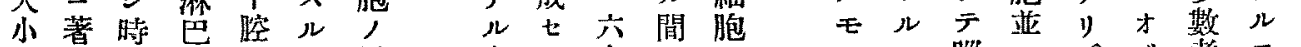

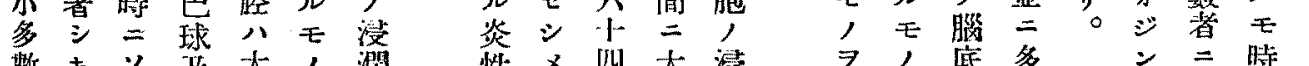

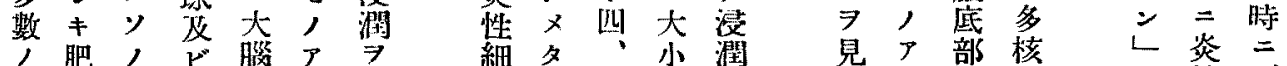

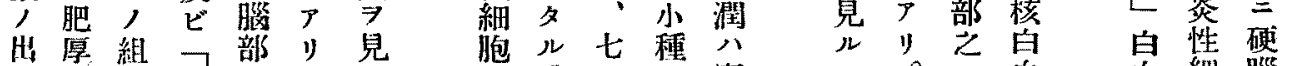

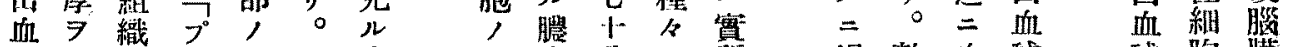

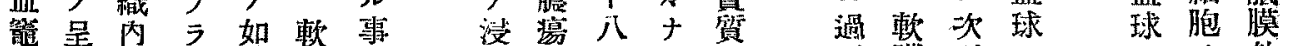

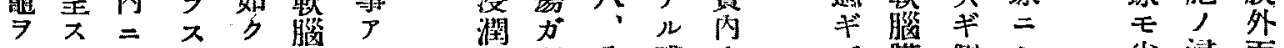

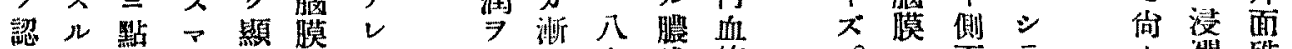

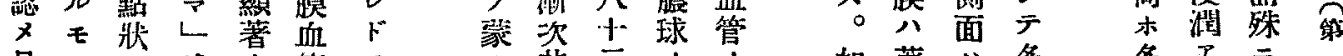
且, \%

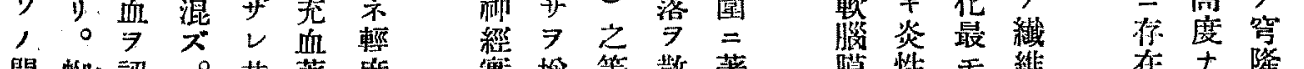

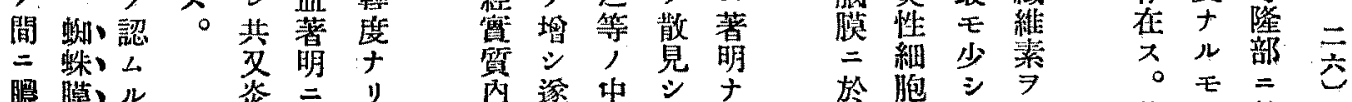

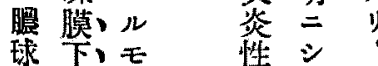

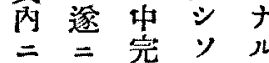
混 其, 於 


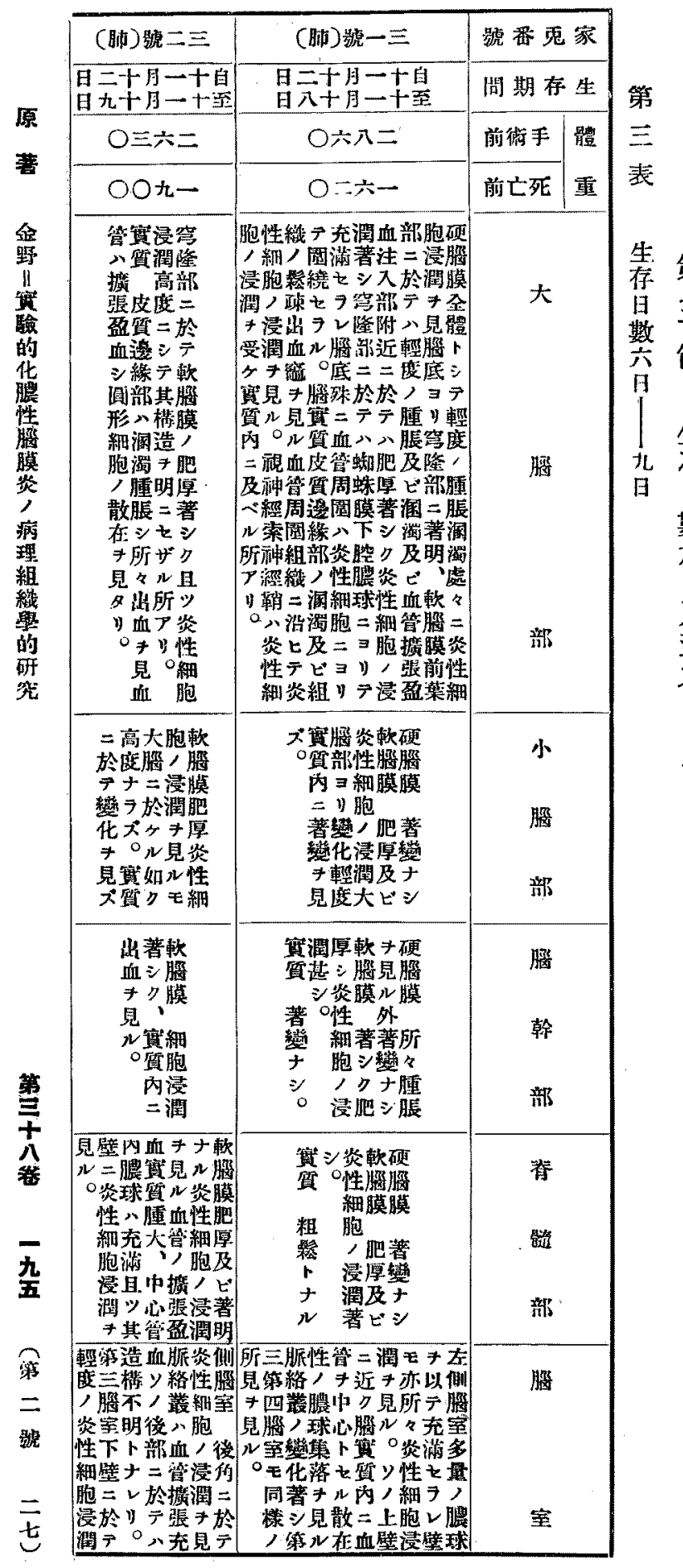

大第、炎炎四蒙蛛三人,

多及、細細腦。時华瓷。落

數 ビ、胞胞室。 = 腔䯕。

例第、人及大八部認

二四、著七゙側、小眼

於腦、シ破腦、不球倁 ラ

テ室、壤宝、同二蛛 ル

八浸 $七$,

第第潤 几第出 リ下モ

第三六７脈公血亏腔，

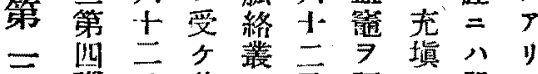

節室望基

共於度り七。出兰

二テナテ第 シ 血士

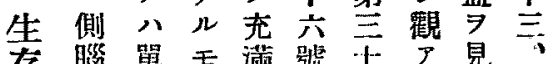

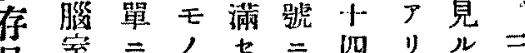

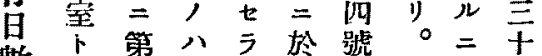

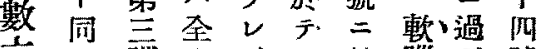

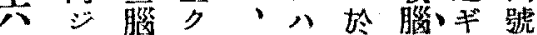

日ク室其脈著亏膜、ザ先

乃炎中構絡變中心ル炎

至性二造細 7 心著モ性

九細液妇胞認管三人 細

日胞性認心メ, ク

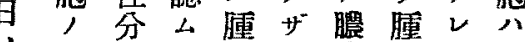

入浸泌儿大ル球䀼ド

モ潤物能 シ 力二

, 7 今細或 $\exists$ 細他部

蒙認ズ胞八リ胞八ト

リム。丙單厂, 概略

ソル而二ナ充浸齐令

, = シ空儿淽潤著同

脈止テ胞粘七著 シ樣

終》炎, 潗亏明

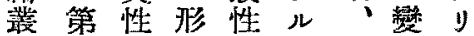

六細成或

化四, リ㵶見王呈

モ䟊浸テ維夕亦シ

亦二潤核性》表硬

側於

㬈亏更側泌炎膜

富八二方物 性亦

$=$ 们其 $=7$ 蕾著

於等周叞藏脹明

分, 園泊 7 ,

ル縤租七ル呈ル

卜化織ル = シ 炎

同 $\Rightarrow$ 内止所性

一見 二, 一 々 細

所得及 $7 v$ 炎胞

見ザべ共性,

马リ儿多絸浸

呈 シ其名胞潤

石, 他八,

○ソ厂多著漫蒙

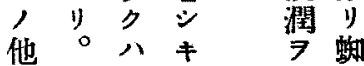




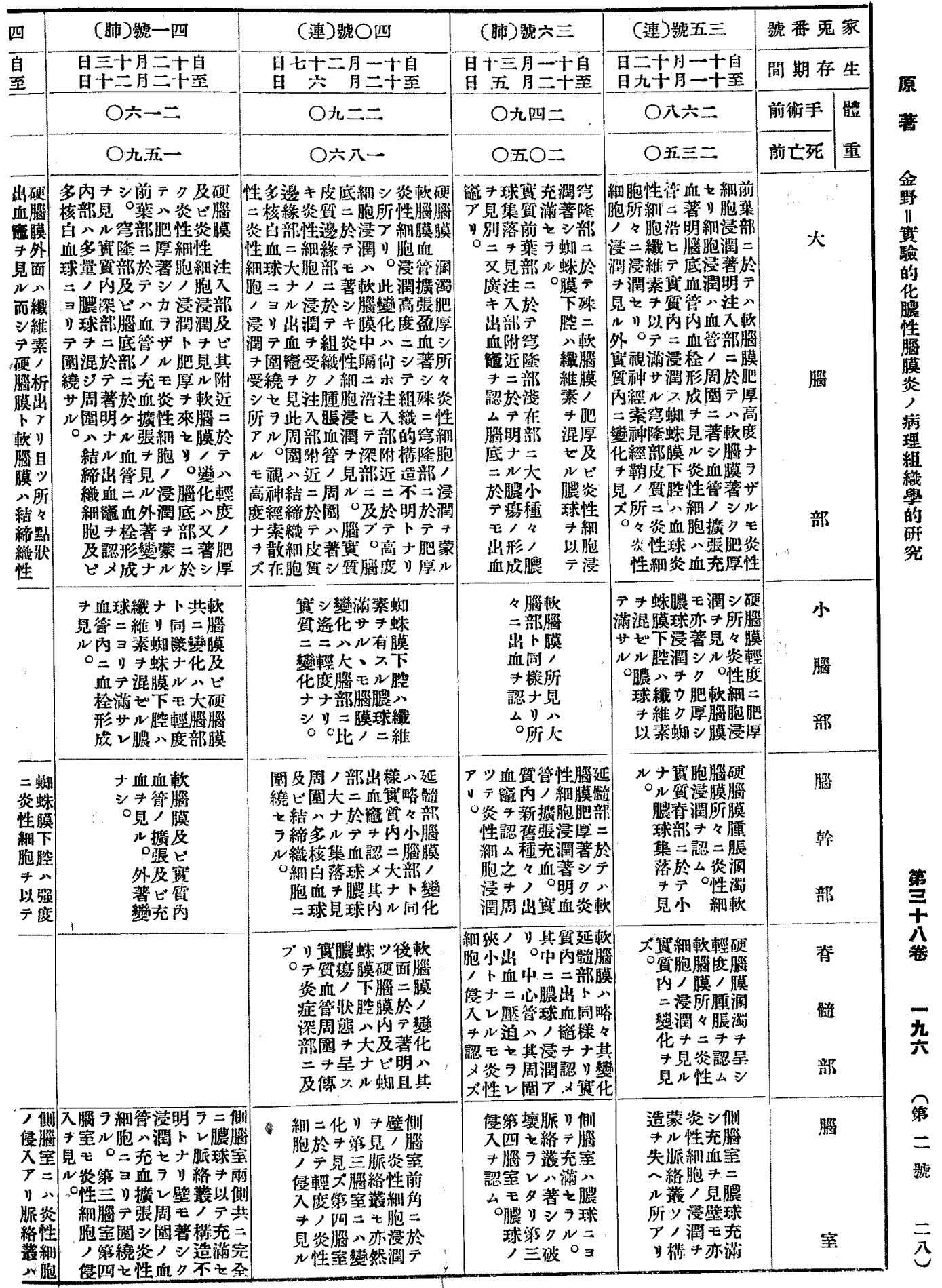




\begin{tabular}{|c|c|c|c|c|c|c|c|c|c|c|c|c|c|c|}
\hline & 買 & 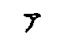 & 蓄 & $\boldsymbol{T}$ & 的 & 園 & 血 & テ & 枵 & 性 & $\rightarrow$ & & & \\
\hline & $\begin{array}{l}\text { 或 } \\
\text { 八 }\end{array}$ & $\begin{array}{c}\text { リ } \\
\text { 其 }\end{array}$ & 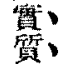 & $\begin{array}{l}* \\
\dot{y}\end{array}$ & 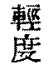 & $\overline{\overline{\text { 於 }}}$ & $\begin{array}{c}\text { 球 } \\
\Rightarrow\end{array}$ & $\begin{array}{c}\text { 小 } \\
\text { 谓 }\end{array}$ & ${ }_{H}^{\prime}$ & 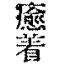 & 大o & 號三七 & (連)皜五四 & (肺)㩆二 \\
\hline & 䯣 & 䦖 & & $L$ & t & $\bar{j}$ & 認 & 形 & 血 & 7 & 腦。 & 日三十月一自 & & 日三ー月月 \\
\hline & 筫 & 圍 & 血 & $=$ & v) & 八 & 4. & 細 & 7 & 楼 & 部o & 日十一月一全 & & 旦计至二 \\
\hline & & 心 & 管 & 斊 & 0 & 紬 & & 胞 & 韶忍 & x & & ○九五二 & & ○五四二 \\
\hline & 1) & 多 & 八 & シ & 炎 & 胞 & 軟 & 結 & 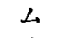 & ル & 礁 & 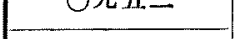 & & 正四一 \\
\hline & $\frac{\text { 度 }}{\sqrt[5]{5 T}}$ & $\begin{array}{l}\text { 校 } \\
\text { 等 }\end{array}$ & $x$ & $\begin{array}{c}\neq \\
\text { 淡 }\end{array}$ & 性 & 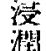 & 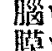 & 䋨 & $\begin{array}{l}\mu \\
E\end{array}$ & モ & $\begin{array}{l}\text { 脑、 } \\
\text { 膜, }\end{array}$ & OC四二 & & $0 \div 0=$ \\
\hline & 2 & Ifli. & $=$ & 㬹 & 胞 & 最 & 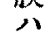 & 性: & , & $\gamma$ & & 湔蝴䛌得 & & 染腰部， \\
\hline & J & 球 & 据 & 1 & 八 & $\underline{\varepsilon}$ & 血 & 細 & $\gamma$ & リ & 外 & 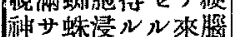 & 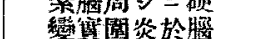 & 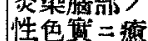 \\
\hline & 移 & 及 & 張 & 桡 & 期 & 藷 & 聟 & 胞 & リ & o & 面 & 腰潤所所七脘 & 化啠二性テ膜 & 細不留於害 \\
\hline & 行 & ビ & 态 & 7 & 蛛 & 明 & $j$ & 证 & $\circ$ & 硬 & $=$ & 溸正下キファリ & 才逪於縕八公 & 胞良穹デ \\
\hline & 部 & 幼 & 血 & 有 & 哭 & + & 掉 & $=$ & 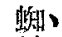 & 覆 & 於 & 貿谐ウレリ & 海 一胞肥首 & ，卜隆想才 \\
\hline & $=$ & 葆 & シ & 及 & $T$ & !) & 張 & $\underline{E}$ & 㘳朱、 & 膜 & $\ddot{\gamma}$ & 周二メク共 ${ }^{\circ}$ 傐面 & 部然二 & 集ナ部シも \\
\hline & 於 & $t$ & 奴 & ル & $\|$ 空 & 0 & 及 & 太 & 膜、 & 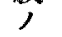 & 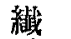 & 虽中被外二 & E & 楁レ=时 \\
\hline & $\bar{r}$ & ル & 鄮 & E & $=$ & 沿 & ビ & 絧 & F、 & 琎 & 維 & 脿著著隔分膜二維 & 性底子瘜战 & 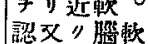 \\
\hline & $\widehat{P}$ & 䋨 & 䢬 & 大 & 於 & 末 & 充 & 胞 & 腔 & 厚 & 素 & 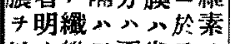 & 絧二强著テ & $\angle 之 大$ 膜得 \\
\hline & 第 & 碸 & 穛 & 緗 & ケ & 炎 & 血 & 等 & 心 & 心 & 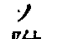 & 以斗維又不佮デ， & 胞沾度 & 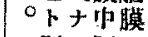 \\
\hline & $\equiv$ & 䋨 & 部 & 胞 & $\mu$ & 症 & 份 & $\exists$ & 硬 & 藷 & 附 & F儿点勥明木所析 & ハデ二是熹 & 别ル弯二 \\
\hline & & 性 & 心 & 等 & s & 八 & 木 & y & 腅 & シ & 算 & 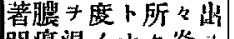 & 浸絸浸れ化 & $=$ 婴於 \\
\hline & 六 & 緇 & 所 & $j$ & 间 & 軟 & 著 & 成 & 膜 & $\eta$ & 炎 & 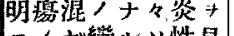 & 潤化潤 & 濯血桨资 \\
\hline & & 胞 & K & 增 & $\ddot{*}$ & 膜 & 明 & 1) & 1 & シ & 性 & 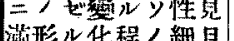 & 幚 & 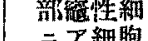 \\
\hline & & $=$ & 炎 & JыL & ク & 中 & ' & 多 & 影 & $\bar{r}$ & 維 & 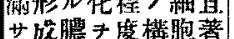 & $\begin{array}{l}z_{0} \\
v\end{array}$ & $\begin{array}{l}=\gamma \text { 緗胞 } \\
\text { 新胞浸 }\end{array}$ \\
\hline & & $\exists$ & 性 & 7 & 多 & 䦽 & 期 & 核 & 腦 & 生 & 胞 & Nキ球示〉造 & 。殊 & 共浸洞 \\
\hline & $\equiv$ & り & 緥 & 見 & 樸 & 7 & let & 白 & 膜 & 存 & 1 & 。見キ七炎潤り & 視 $\stackrel{\text { 和 }}{=}$ & 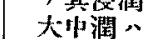 \\
\hline & 栫 & $\bar{\gamma}$ & 胞 & ル & 白 & 介 & 亦 & IIIL & , & 日 & 湾 & 夕以り性認于结 & 动 血 & ナ央著㥠 \\
\hline & $\smile$ & 圍 & 1 & 0 & 血 & $\ddot{z}$ & 著 & 球 & 㿥 & 數 & 潤 & y $\%$ 細メ來厚 & 經 管 & ルハシ后 \\
\hline & 7 & 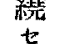 & 㥅 & 然 & $\begin{array}{l}\text { 球 } \\
\text { 莯 }\end{array}$ & 哚 & $n$ & 父 & 者 & $=$ & 薏 & 阴上塩 & 7 选 & 紻木小 \\
\hline & $t$ & $\overline{7}$ & $\frac{\pi x i n}{7}$ & 步 & 晋 & 梠 & シ & $\frac{1+1 \times 2}{x}$ & $\mu$ & 至 & t & 同膜 & ズ膜 & 胞肥臑 \\
\hline & & $n$ & 受 & 染 & $h$ & $=$ & $\bar{\gamma}$ & $\bar{\gamma}$ & 部 & -5 & ル & 㧺 & $\%$ & 一厚新 \\
\hline & 脂 & 0 & ケ & 部 & 減 & 及 & 炎 & 小 & 分 & 旦 & モ & 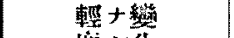 & 譥 & 唛シ顿 \\
\hline & 湯 & Ifíl. & 前 & $=$ & 少 & ح & 辖 & 数 & 7 & $=$ & $\bar{t}$ & 继儿化 & 化 & 潤且盗 \\
\hline & 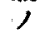 & 管 & Th & 於 & シ & y & 縕 & $r$ & 除 & $f_{i}$ & 7 & $\begin{array}{l}\text { ナモ大 } \\
\text { y土亚 }\end{array}$ & 著 & 都ツ膜 \\
\hline & 形 & 周 & $=$ & テ & 小 & 0 & 胞 & t & + & צr & 1) & 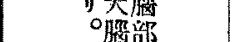 & & 明荻心 \\
\hline & 成 & 圍 & $b_{*}^{*}$ & 或 & 䢙 & カ & I & 1) & $\bar{T}$ & ル & 0 & & T & 性问 \\
\hline & 7 & $\therefore$ & テ & 八 & 形 & 、 & 涭 & 7 & 心 & 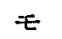 & 内 & メ䪃 & 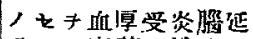 & 曼ル膜去 \\
\hline & 罗 & 炎 & 述 & 腦 & 緗 & $\mu$ & 潤 & $\overline{3}$ & 炎 & , & 面 & テ瀷 & 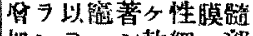 & ク炎八满 \\
\hline & 定 & 性 & そ & 底 & 胞 & 篗: & 7 & $\begin{array}{l}7 \\
x\end{array}$ & 性 & F & $\mp$ & 强㷬 & l高部 & 性肥 飞 \\
\hline & 型 & 維 & タ & 部 & 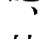 & 化 & 傢: & $\vec{r}$ & 絧 & 比 & 亦 & 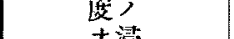 & 著 & 絸厚 \\
\hline & 的 & 胞 & ル & $=$ & 結 & 八 & i) & $\overrightarrow{\mathrm{r}}$ & 胞 & $\dot{*}$ & 炎 & $\begin{array}{l}\text { 于㴗 } \\
\text { 潤 }\end{array}$ & 締シ炎所 & 胞芯。 \\
\hline & ナ & 1 & $₹$ & 於 & 綡 & 驾 & 棈 & 球 & $=$ & $\bar{\tau}$ & 性 & 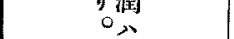 & 縕浸䍃 & 潤明顿 \\
\hline & N & 沒 & , & $\bar{T}$ & 織 & 隆 & 造 & 亦 & $\exists$ & 箽 & 組 & 栖 & an & $\neq+1$ \\
\hline & 震 & 潤 & $\exists$ & 多 & 絧 & 部 & , & 㑇忍 & リ) & $=$ & 胞 & & 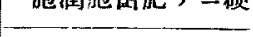 & \\
\hline & 竞 & $\exists$ & 少 & 格 & 胞 & 仗 & 著 & $x$ & $\bar{\tau}$ & \% & I & N & 增月 & \\
\hline & 胋 & 藙 & 更 & 白 & 泣 & ビ & $\dot{*}$ & ラ & 尤 & , & 浸 & 部硬埂膹 & 加膜儿蛛 & \\
\hline & $\overline{7}$ & v) & $=$ & 血. & $=$ & 烅 & $\eta$ & $u$ & 荋荫 & 悬 & 潤 & 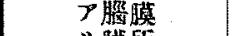 & *'所膜 & \\
\hline & 有 & 其 & 高 & 球 & 形 & 底 & 不 & ० & セ & サ & 商 & 》膜所 & 見結つ下 & \\
\hline & $\lambda$ & 緮: & 度 & 7 & 大 & $=$ & 明 & 然 & ラ & 7 & 度 & OF & N祒り膛 & \\
\hline & & 化 & ナ & 倘 & $=$ & 柉 & F & $v$ & $n$ & 埼 & $=$ & 然范迎 & 粰且 $=$ & \\
\hline & & 深 & ) & 木 & 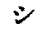 & テ & ナ & 共 & o & Jin & シ & & 細以徏 & \\
\hline & & 部 & & 多 & $\bar{\gamma}$ & 荎 & $v$ & 沿 & $y$ & $\ddot{*}$ & 5 & & & \\
\hline & 經、 & $=$ & 實 & 數 & 原 & 明 & $n$ & 本 & , & 且 & 時 & & & 胞澱第受 \\
\hline & & 及 & 質 & $=$ & 形 & $=$ & 所 & 所 & 炎 & $\%$ & $=$ & ラ絡制ブ得 & 化蔫藷 of & 浸室 \\
\hline & , & $\infty$ & 肉 & 認 & 貿 & シ & $\gamma$ & 々 & 性 & 縕 & 軟 & 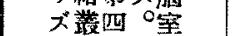 & 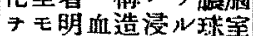 & 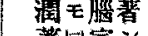 \\
\hline & 第 & リ & 所 & $厶$ & $=$ & $\bar{\gamma}$ & リ) & 多 & 維 & 緎 & 胋 & 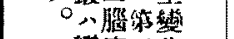 & 同 管不泪脈 $\neq$ 前 & 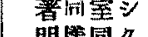 \\
\hline & D & & \& & ル & 檪 & 側 & & 敖 & 胞 & 内 & 膜 & 繁室三化 & 力橉第，明二絡以的 & 明睆问方 \\
\hline & & 而 & $=$ & 所 & $i$ & 面 & 血 & 1 & 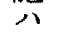 & $=$ & $r$ & 化王版著 & 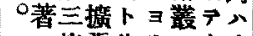 & \\
\hline & 五 & $\ddot{z}$ & $H$ & $\gamma$ & $\neg$ & 心 & 然 & 多 & 主 & 所 & 結 & 著同窟分 & シ第䬭化 》， & 性第㞸 \\
\hline & $u_{7}$ & $\bar{\tau}$ & dft. & 1) & ${ }^{2}$ & 比 & ' & 核 & 上 & $A$ & 䋨 & & & 紐四明 \\
\hline
\end{tabular}




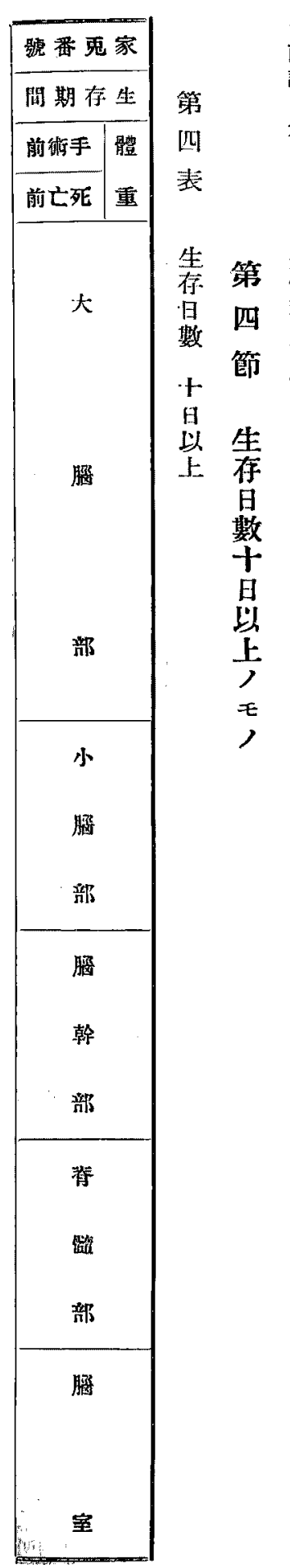

ᄂ

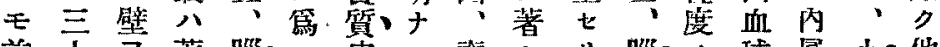
前 $干$ 著腦。二皮ル脊。シリ腦。，球展小他

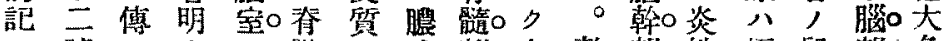

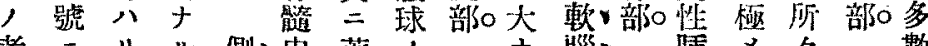
者二リル側中著; ナ腦、腫メ\&數

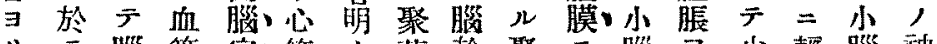

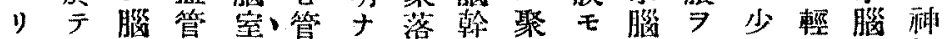

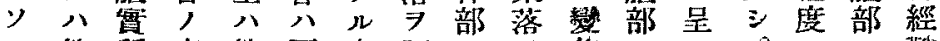
, 第睤充第壓炎認, 7 化卜ス。, , 鞘

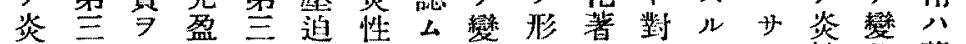

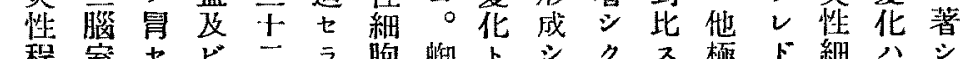

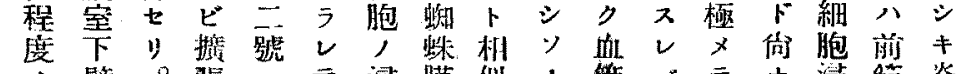

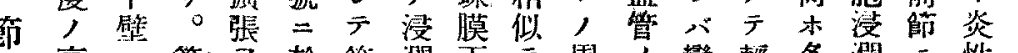

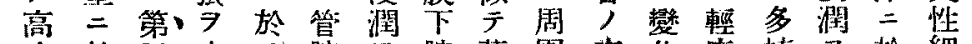
度於

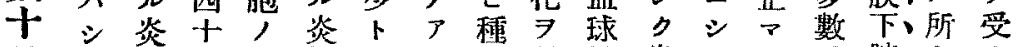

日公性號浸性ナリ呈及炎テレタ腔、トケ

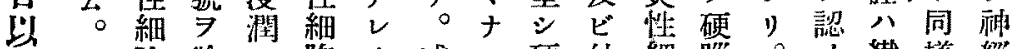

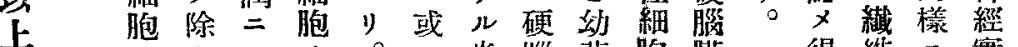
, 手, 。炎腦若胞膜 浸, 》浸而更性膜子, 只

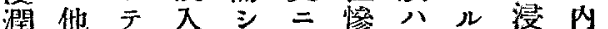

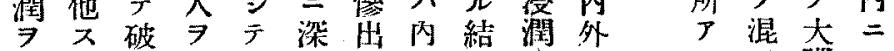

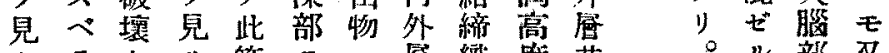
タテセル等二二唇織展共

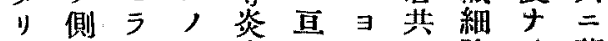

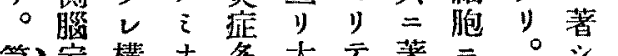

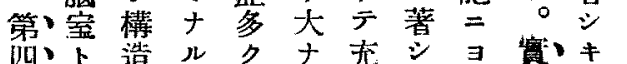

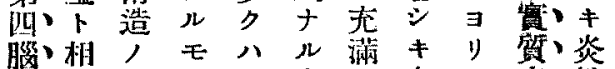
咅似不爾血出七炎示丙性 モ明他管血亏性園二細

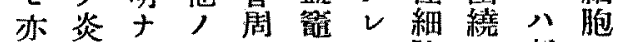
略性儿多園 $尹$ 、胞七澵

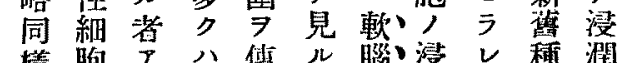

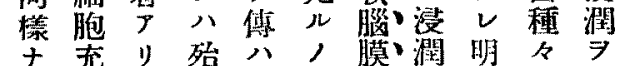

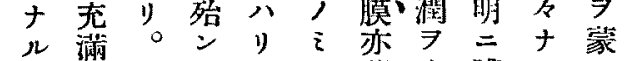

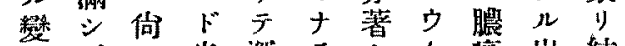

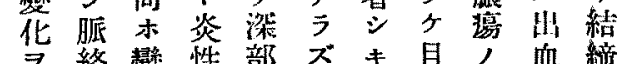

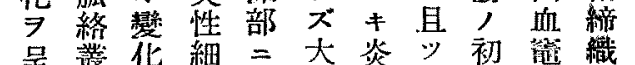

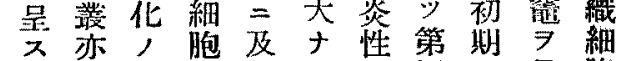
。破㯬二公儿細四上見胞 斯壞 僌、澧 $=$ 焱 腦、球 比性 膜、 $=$ 細 㫓 $\underset{\exists}{\bar{\tau}}$ 胞 厚 多充少㵎 多霂 シ 八七。見 萻今硬、ル 明盟、所 シ テ'外。 炎炎展 細細 於 胞盷 テ 浸小殆 , 如

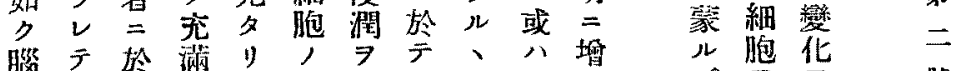
室り旺七。聚受八モ血加 , 八5落分其, 球至

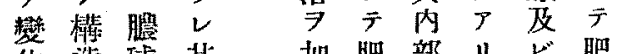
花造球其扣肥部り芯肥

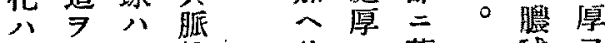
何失更絡 此著球 $\rightrightarrows$ 梄、主 認 質、卜 $x$ 表多得 面核 ル 


\begin{tabular}{|c|c|c|c|c|}
\hline 躆二七 & (䀑) 號一七 & (速)號九三 & 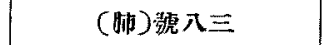 & (肺) 踥七三 \\
\hline $\begin{array}{l}\text { 日九月一自 } \\
\text { 日九十至 }\end{array}$ & $\begin{array}{l}\text { 日早月一息 } \\
\text { 日公十月一至 }\end{array}$ & $\begin{array}{l}\text { 昌七十二月二十夏 } \\
\text { 六 }\end{array}$ & $\begin{array}{l}\text { 昆十二月二十䚁 } \\
\text { 呈 }\end{array}$ & $\begin{array}{l}\text { 日七十二月二十筫 } \\
\text { 公 }\end{array}$ \\
\hline$c=二=$ & O九三二 & $0 \rightarrow==$ & $O \equiv \equiv 二$ & $\mathrm{O}-二=$ \\
\hline ○五九一 & O七ス一 & $000=$ & $\mathrm{O}-\mathrm{O}=$ & $\mathrm{O} \equiv-二$ \\
\hline 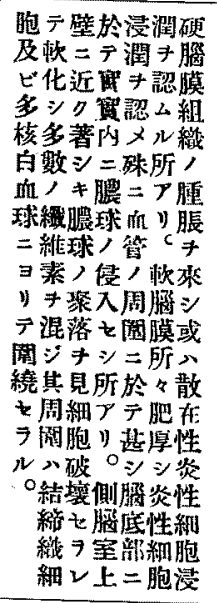 & 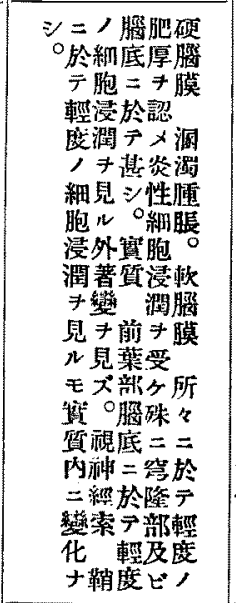 & 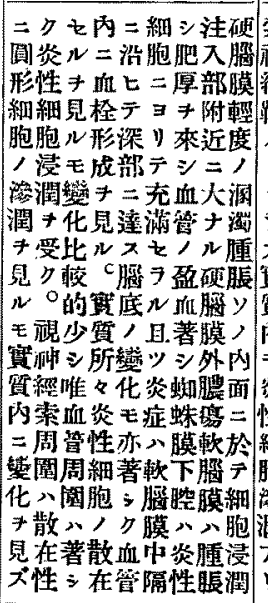 & 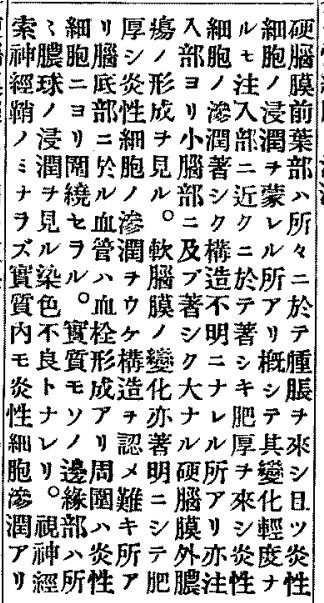 & 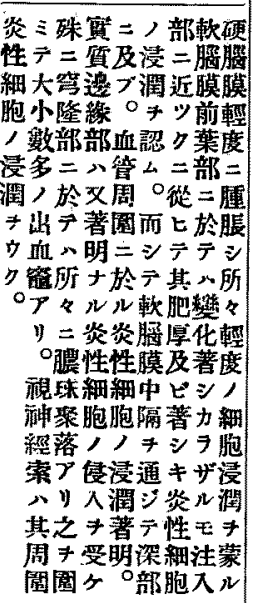 \\
\hline 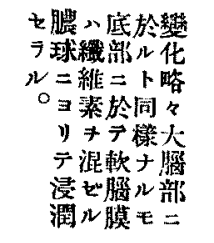 & 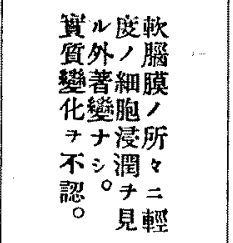 & 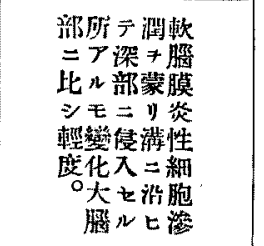 & 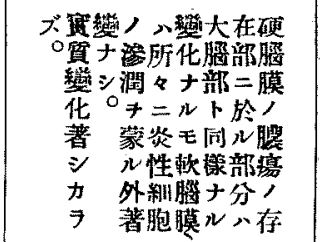 & 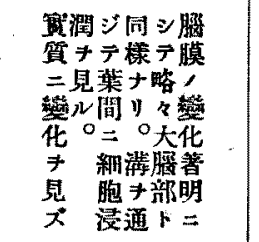 \\
\hline 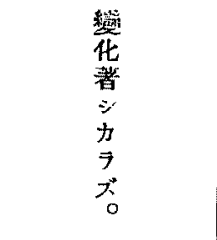 & 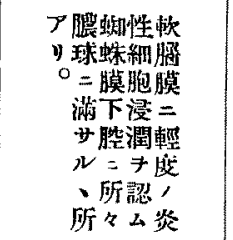 & 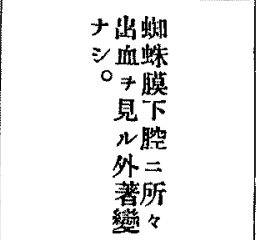 & 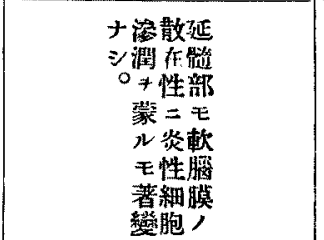 & 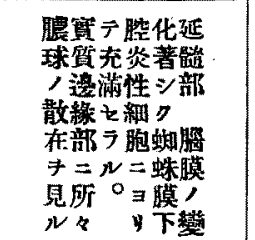 \\
\hline 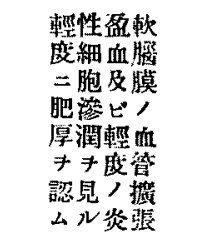 & 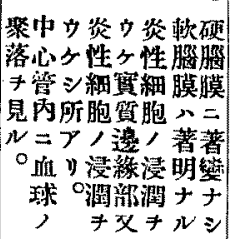 & 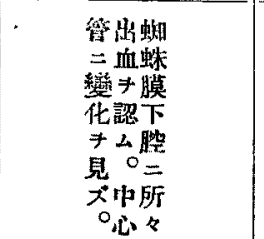 & & s \\
\hline 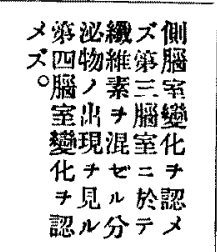 & 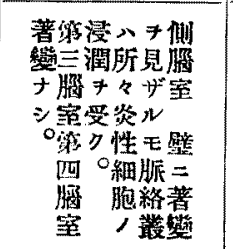 & 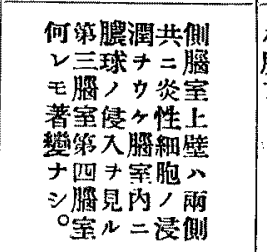 & 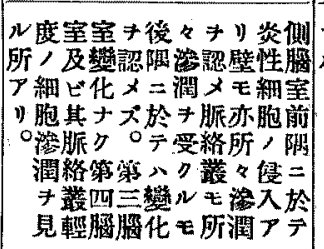 & 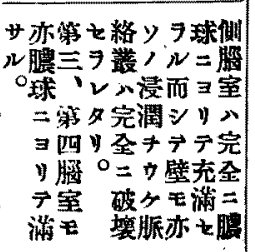 \\
\hline
\end{tabular}




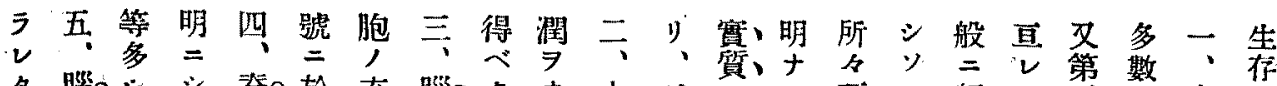
儿㭡。

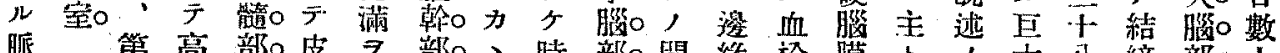

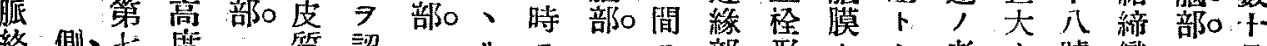

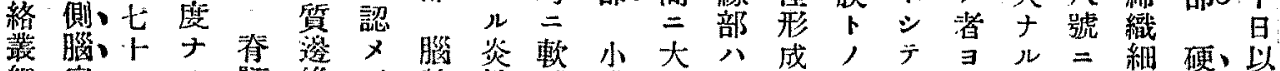

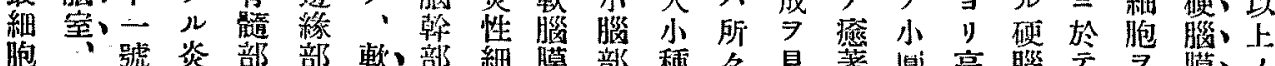

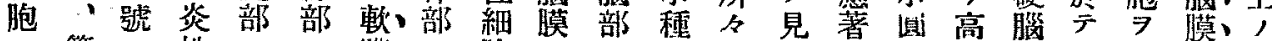

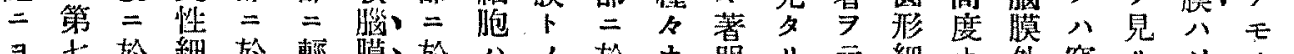

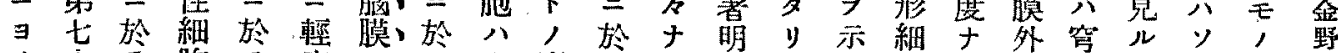

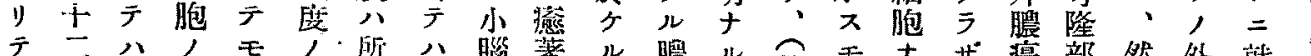

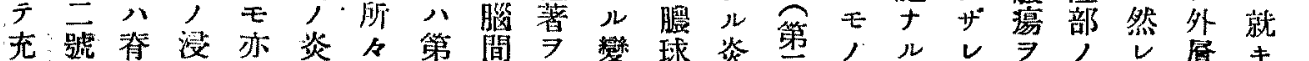

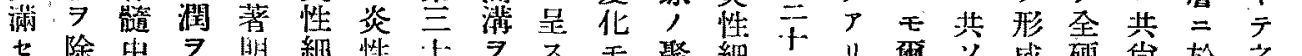
ラ除中

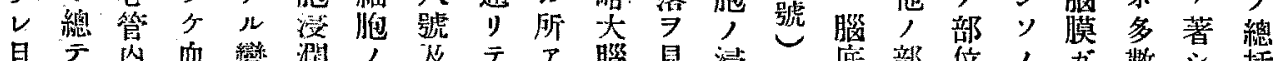

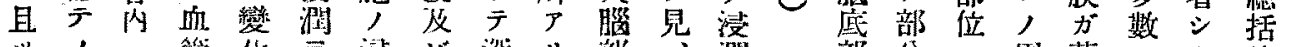

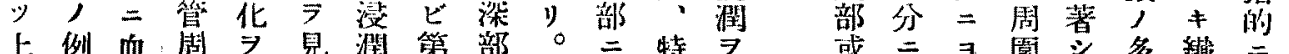

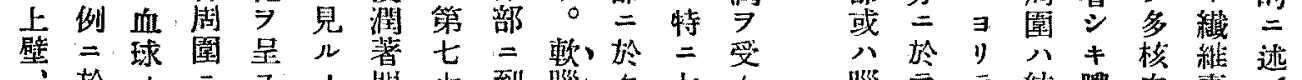
於

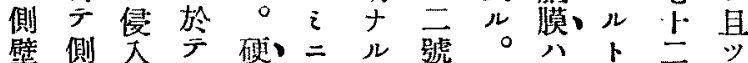

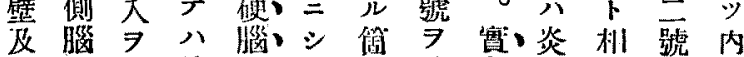

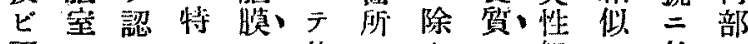

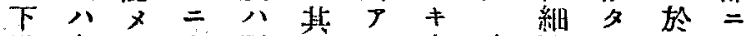
壁炎夕小肥他と多韯胞と方於

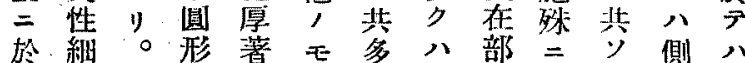
厂胞緗奛, 少二主, 腦血 モ, 胞倍二分腦於占程堂管

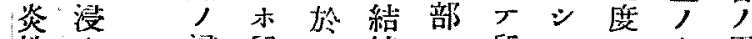

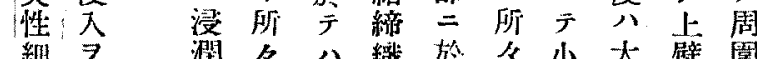

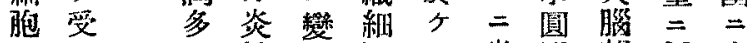
, 性化胞儿炎形部近大

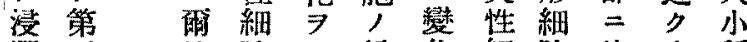
潤兰他胞認䇎华細胞比定種

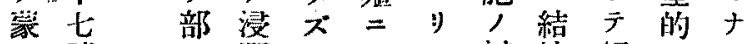

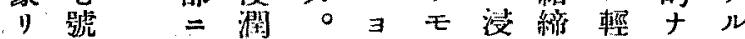
眽 $=$ 於 $\Rightarrow$ リ秒入織碾儿出

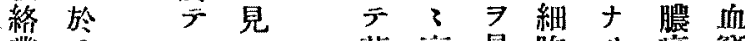

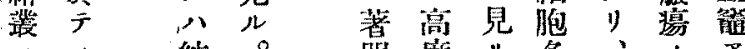

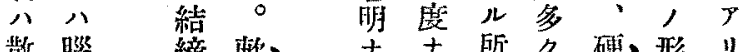

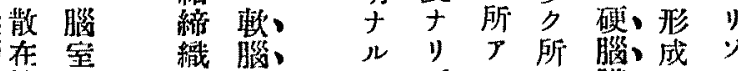

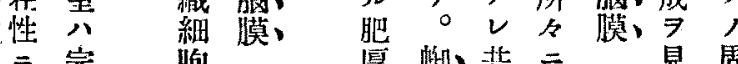

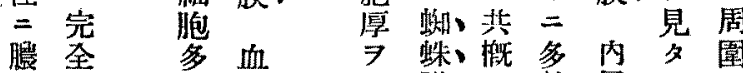

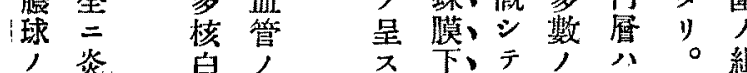

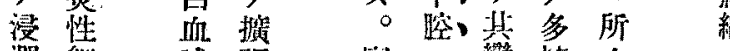

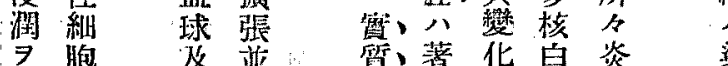

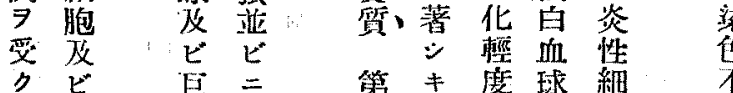
兄破 夸充第炎度球緗良

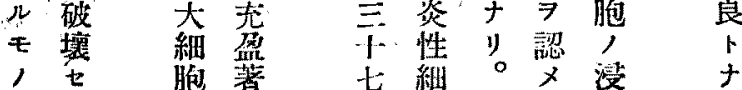

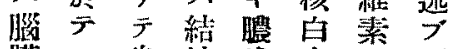
膜八俑䧛球血; 可 中主本緎, 球附方。

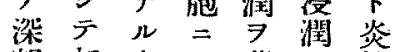
部新充 $\exists$ 蒙 7 性 二琵血りり兄細 於種 $\Rightarrow$ テ非 テ \& 認園精部, 八十 $\times$ 穑不分漫 佔 ル 得 $t$ 明 $ア$ 潤 木 結 ル

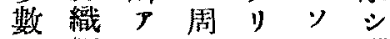

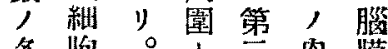
多片。卜三内膜 核 $\exists$ 血明 白り管 $=八 二$ 體 血成, 區號於 球り周敖及文 シ 所園セビ 页テ

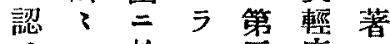
$x=$ 於 得淋宁。可人 二只八㜞儿小昍

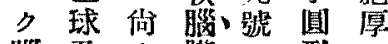

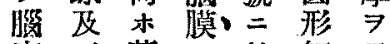

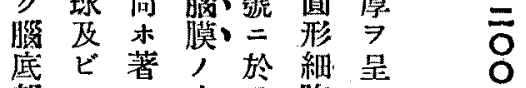
部 品血テ胞 シ $=7^{a} \neq$ 管八組 於 万炎, 炎浸織第

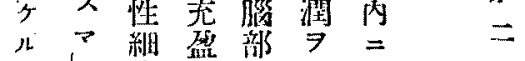
血求胞芯寻所新路

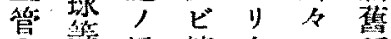
队等漫摫小 = 種

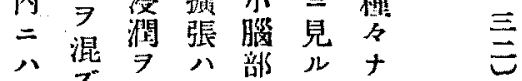
原 著

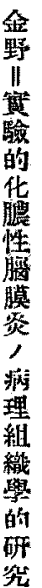
笋
$\stackrel{7}{\text { 兊 }}$

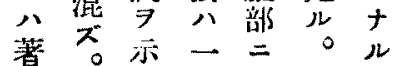




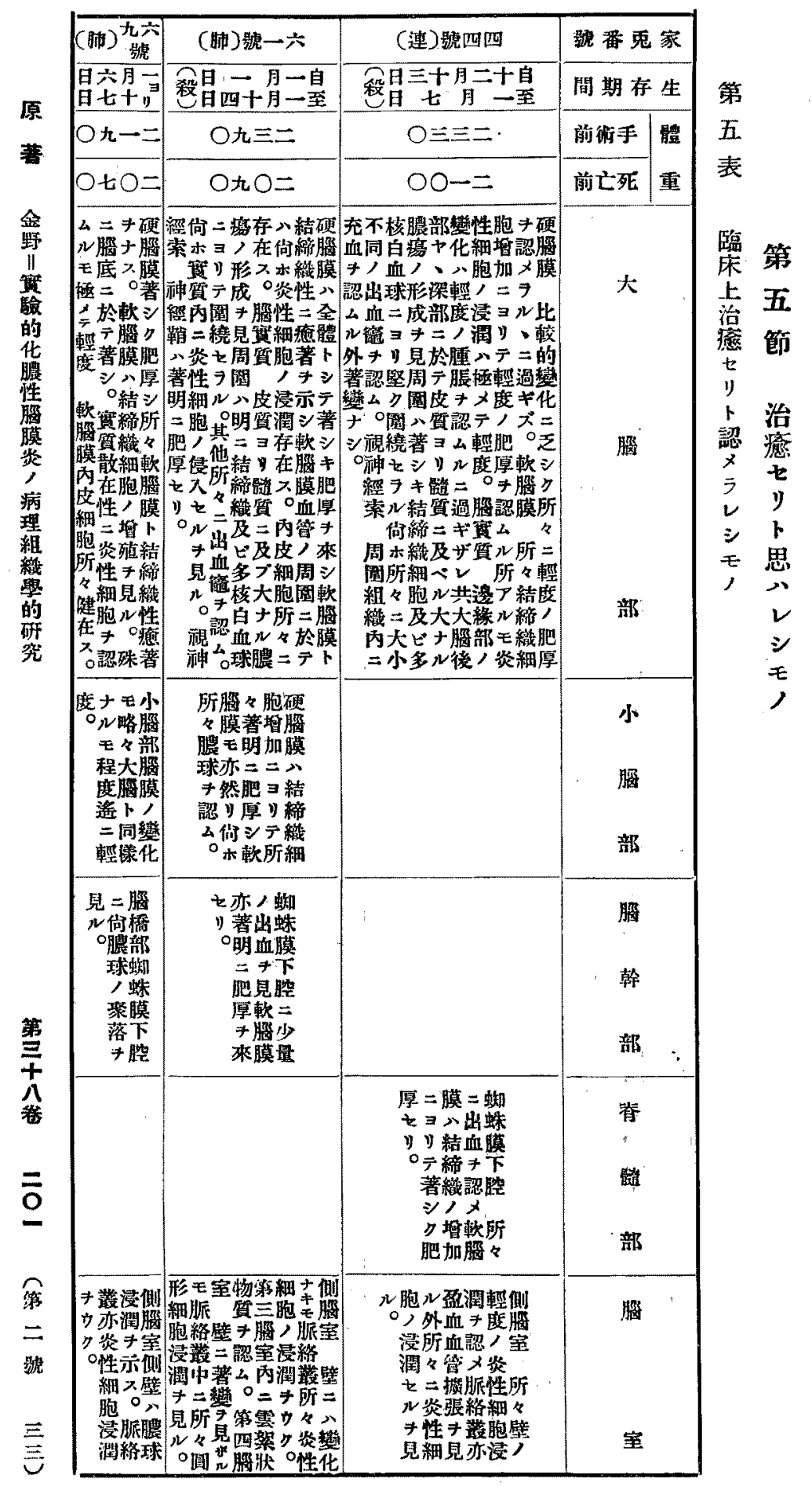

スル 以り第

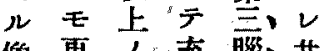

候更人无腦共

$\Rightarrow$ 三 所"夕室就

見㕛見开及、中

タ 新 $コ$ ビ、脈

リ鮮り脈第、絡

○ナ本絡 四、荛

ル群 浸 腦、絴

出 二王室、胞

学第完

來八シ”全

シ之”夕十 =

多以侵七破

核前开號壤

白死 $v=$

血 $=$ 於 $\overline{7}$

球到.

ノレ造ハテ

多ル櫣 兩 y

數モ不者

，，明共檏

游二卜全 造

出此ナ方

来

七結 $0=*$

幺締侵得

所織若 ザ

厂細次

リ胞第、モ

$\div \quad 2 k$

$\rightarrow$ ヒ

方

$=$ 太

於 細

テ 胞

治 前

的淋

傾 邑

向'絴

$\Rightarrow$ 胞

示 等

他多於

方

$=$ テ

扎明

学 $=$

双治

新虔

$=$ 的

炎 傾

造 向

, 7 ,

進 示

行

$\Rightarrow$ 所

意 7

倲見 


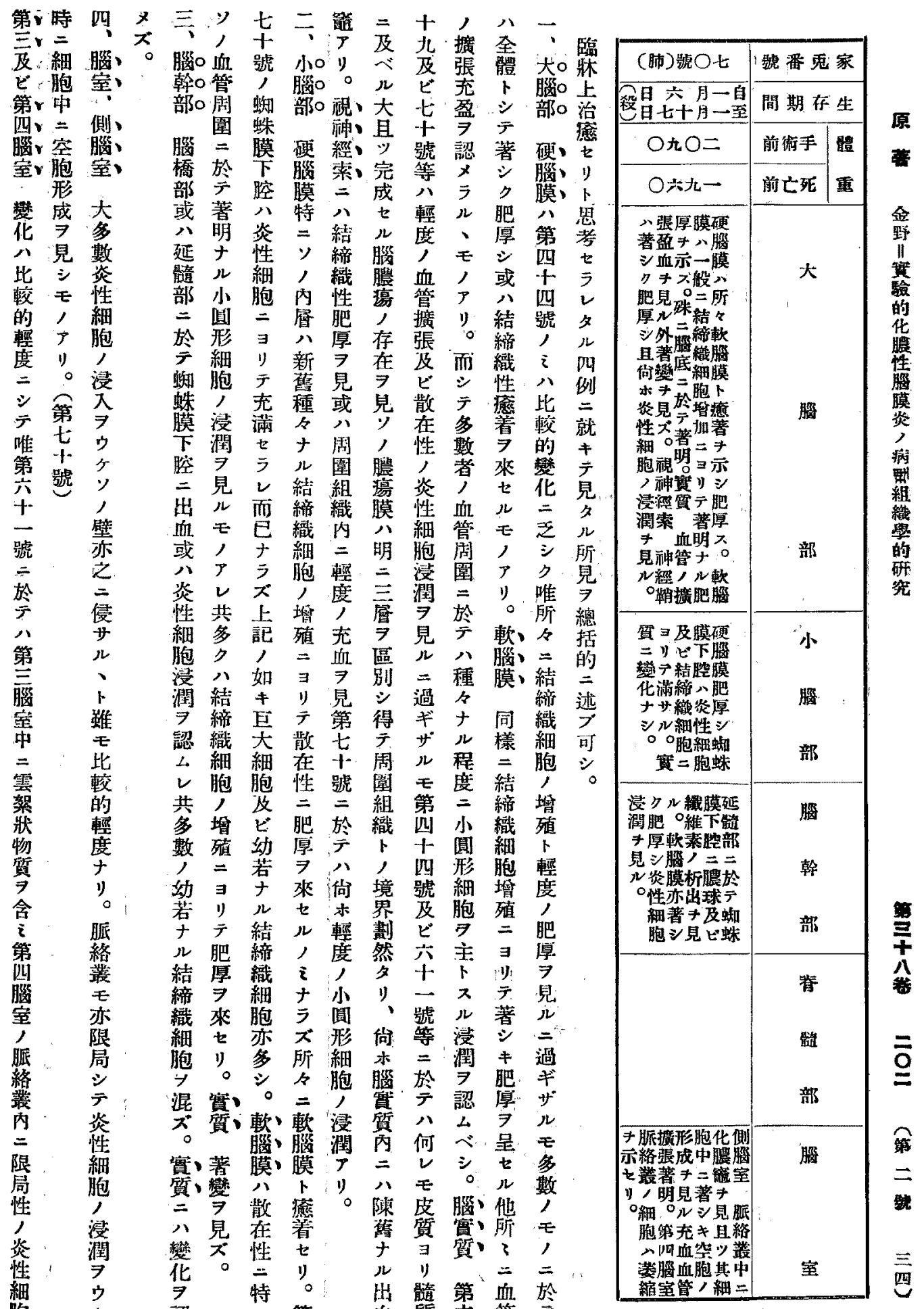


$ル$ 等 7 椟 7 球

二見白見等軟

拘亦能, 血儿八腦

今增木球。多膜

IS

他 $、$ 次等 血惹

面而り第, 管趋

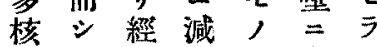

白テ過少二治ル

野血興当当於比、

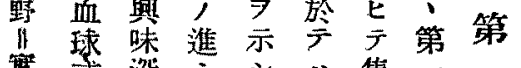

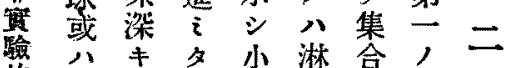

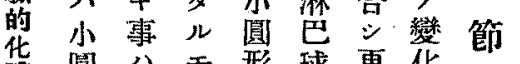

化圆少モ形球更化

性形比, 細蓝 =

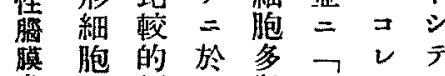

竾胞經 テ數 ブョ分腦

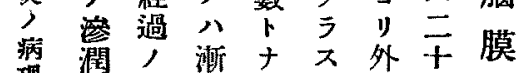

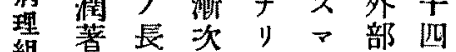

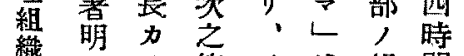

學 ニ 等 ソ球組間

的 $シ *$ 種, 等織生

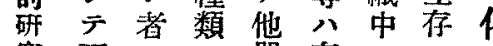

究更 = , 單存二,

二於緗核在游诸

新示胞 細 ス出二

今 7 胞ル七於

夕軟 增 ニモンテ

ナ腦加 シ 極卜見

儿膜 ス テ ス ル

炎,, 原 $\neq$ 如

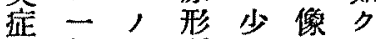

地 部 $i$ 質 $三 \exists$ 血

撗於 う富 更

大 $テ$ 市 $i$ 得旗

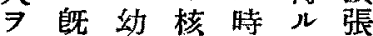

思二若光モ支

第 八結 ナフ

当シ䋨儿ク經ア充

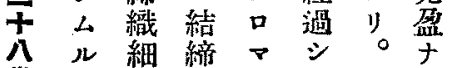

溇部胞織千夕哴り 分增 細 ン

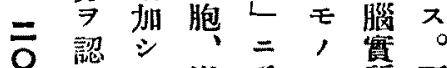

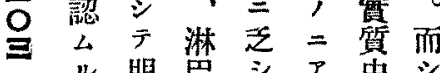
ル明芭 シ ア 中 シ

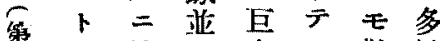

一 + 治二大八政核

二

㩆。的ブル三性血 監傾 ラ 細 $\vec{I}=$ 球

二牀向 $又$ 胞五侵及 吾上

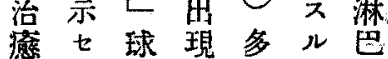

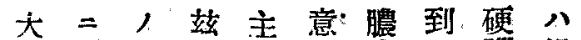

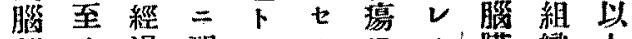

部 $\frac{1}{=}$ 過 現 三

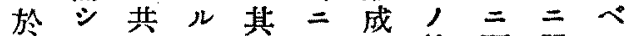

テテう、离 シ シ 等 顯 單

最之此, 病, 面テ全種著ナル

七 等多的寻民組令ナル:余

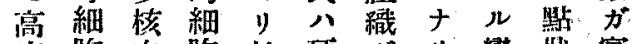

度 胞白胞始硬方 リ篎, 狀 實

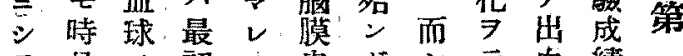

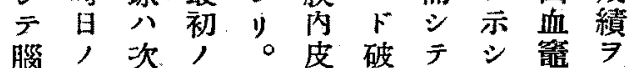

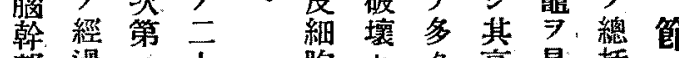
部過 三下胞七ク高見括 奉卜減四心ラ, 度儿天 軟鹃共少時: 甚 部 $=$ 共 ダ 合ル週バ

强儿硬モギ硬胋

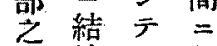

キ二畽, 次織目 兵增細多 綕腅加胞核 部 於方締球 多絨 ルシ細主 楚 テ胞 ト 化硬或 八䀝 心 最膜原硬 モ心形胋 签著留 膜 少 シ 富 維

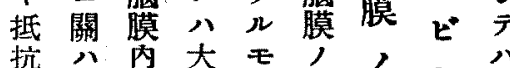

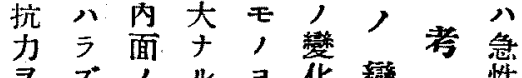
有 其繂 膡

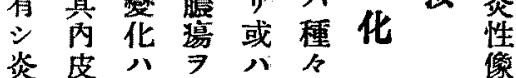
性 外 7 形

性 細 外形 其 二 潐光 $=$ 面成戀 シ 行 $i$ 比或 $x^{\circ}$ 二八济主,

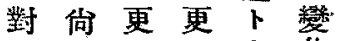
テ 木 $=$ 末 强淮 防 来嵹進 テ 硬 程

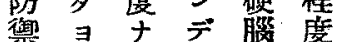

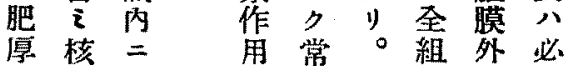
$\exists$ 或 $\rightarrow$ 態茲織 $=$ シ

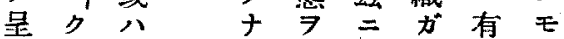
ス口聚 ス存鼠炎り經 ルマ落者七味性 $\dot{\text { テ }}$ 過

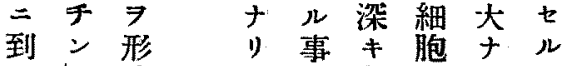
ル上成上曾所, $\therefore=$ シ 記 ナ見浸硬數

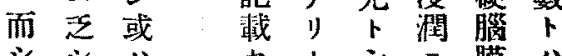

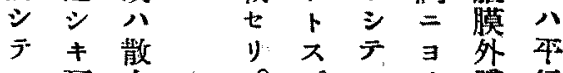
一亘在: 。只少膿行 般大性而此硬亏湯七

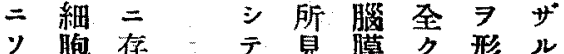
, 等程 硬 $八 内$ 其成

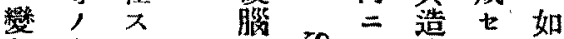

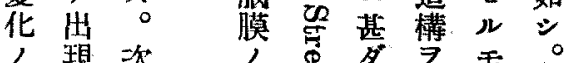

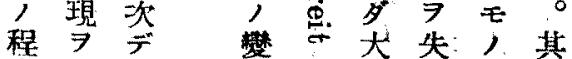
度見炎化, 小走
浸

本 三 柇 营 著 總 硬 括 及 シ 消 退 $=$ $\bar{\gamma}$ 俉 例

於 于 発 症 進 行 意 즈 所 見 見 * 


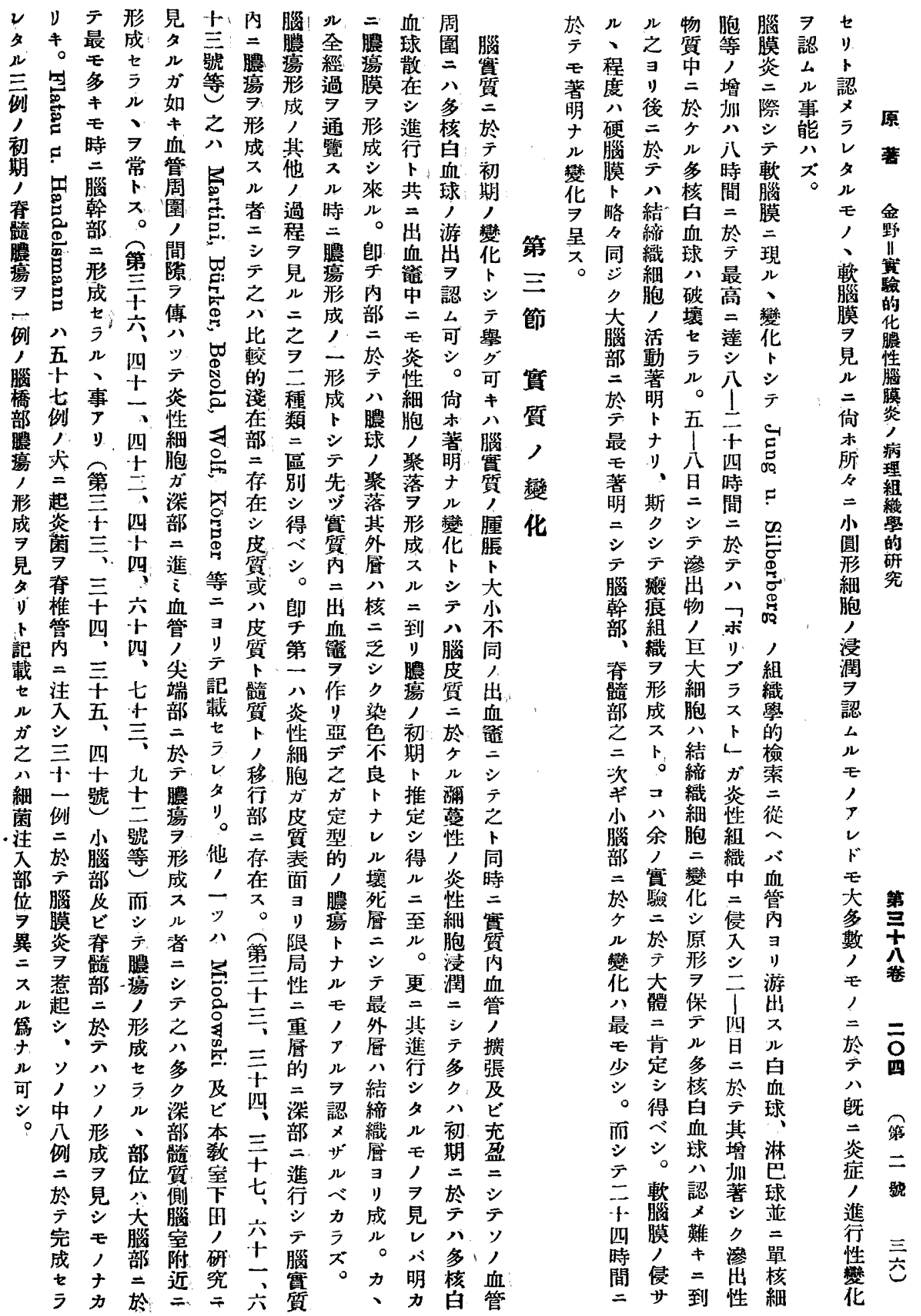


几胞夕度壁 膿モ余 几

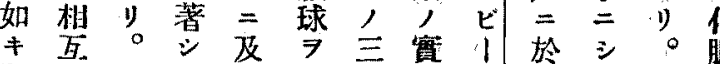
所, 第力

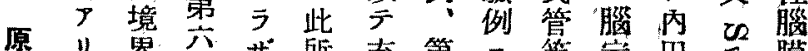

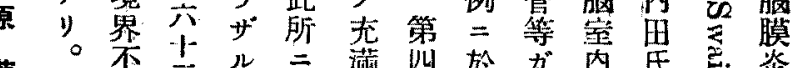

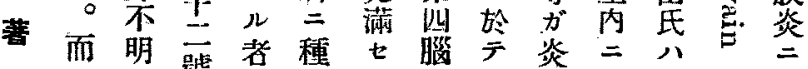

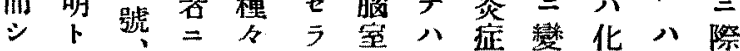

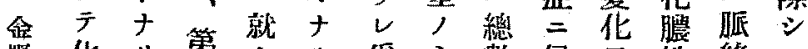

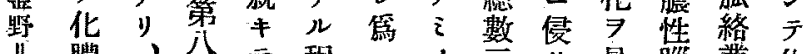

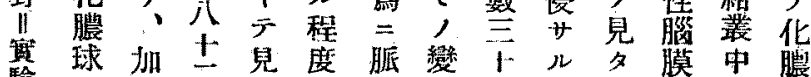

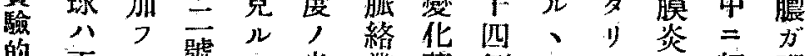

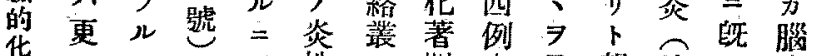
膿 = 二 \% 笙 公明中見報連二室

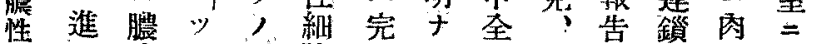

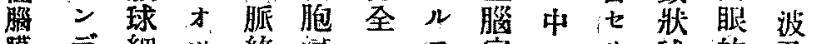

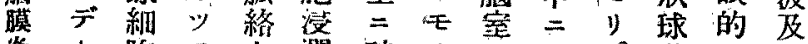
炎上胞テ上潤破, 公八。菌三

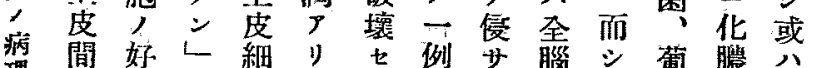

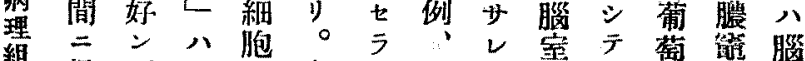

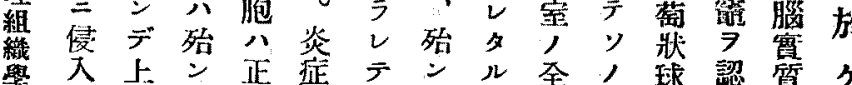
的シ皮ト常比ソトモ全菑藏㑇留

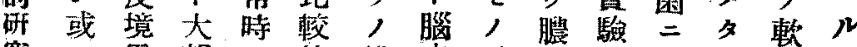

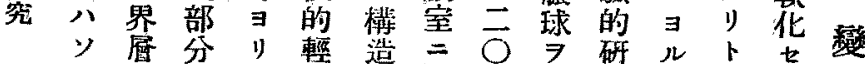

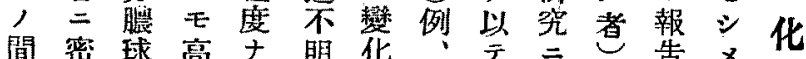

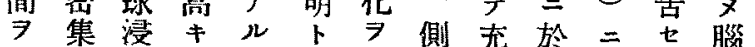
通

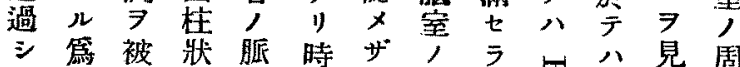

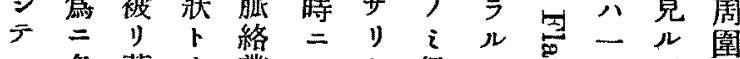

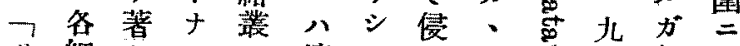

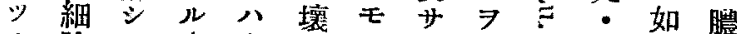
才胞

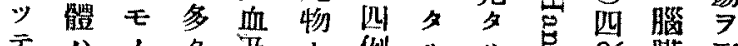
テ八, 及采例ルリ员\%膜形

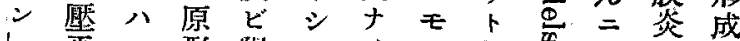

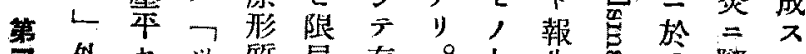

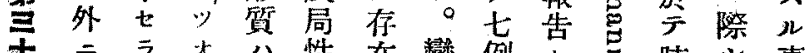

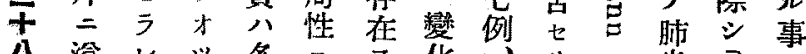
公溢レッ多二又化、り, 八炎テア

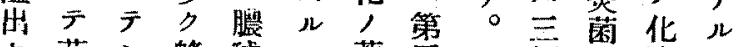

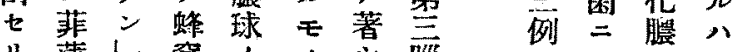

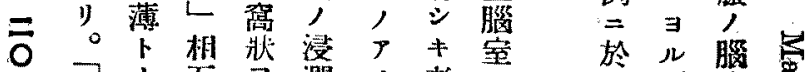

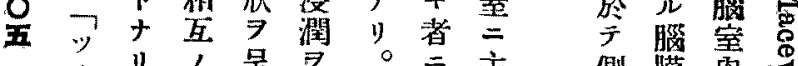

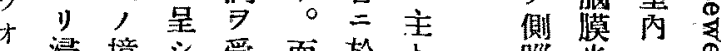

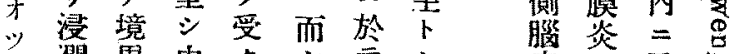

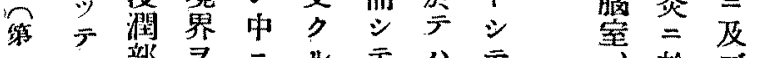

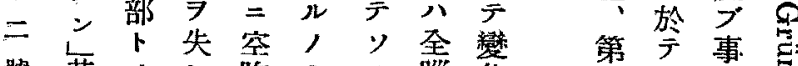

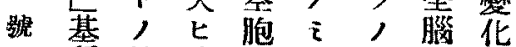

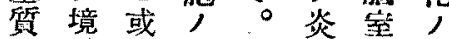

= 二界八形破症里存

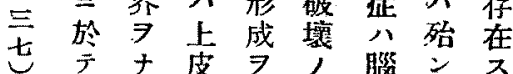
ハナ皮胃程室だル
夕續 斷 葚 而號余

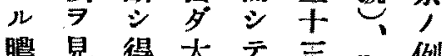
滣見得大テ主初例

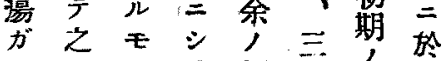

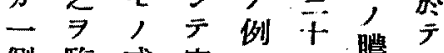

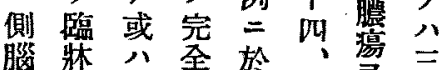
室上不圭等三界市 =了幸儿椹思四 第 破經 = 堙多五、例

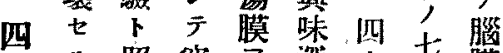
節 像合然有梁號例膜

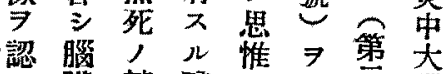

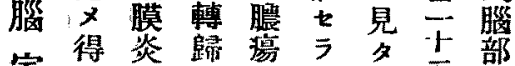

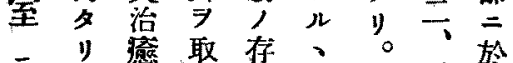

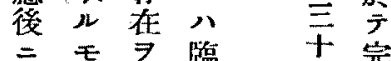

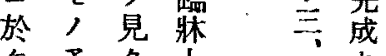
\% $>$ 上

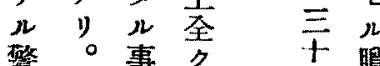

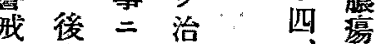

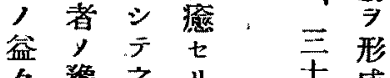

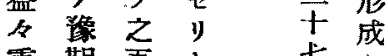
重期吾息: 七七 要を令思喵

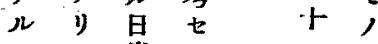

音常

感演臨夕四 ス吕獎兄 士第 余遂 於例六市 第禽、胹第 主六 七破染四 號芰

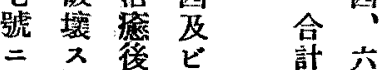
於 $九$ 六古十

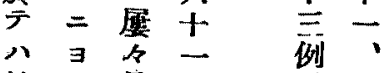
始当見號六

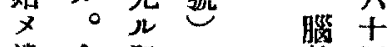
滚 今所二幹四 稼 斯 二 於 部 部 $\dot{*}=$ $=$ 如 $\sigma y$ 於 形幸, 索二 成實亡赛 四 等成喰第声 


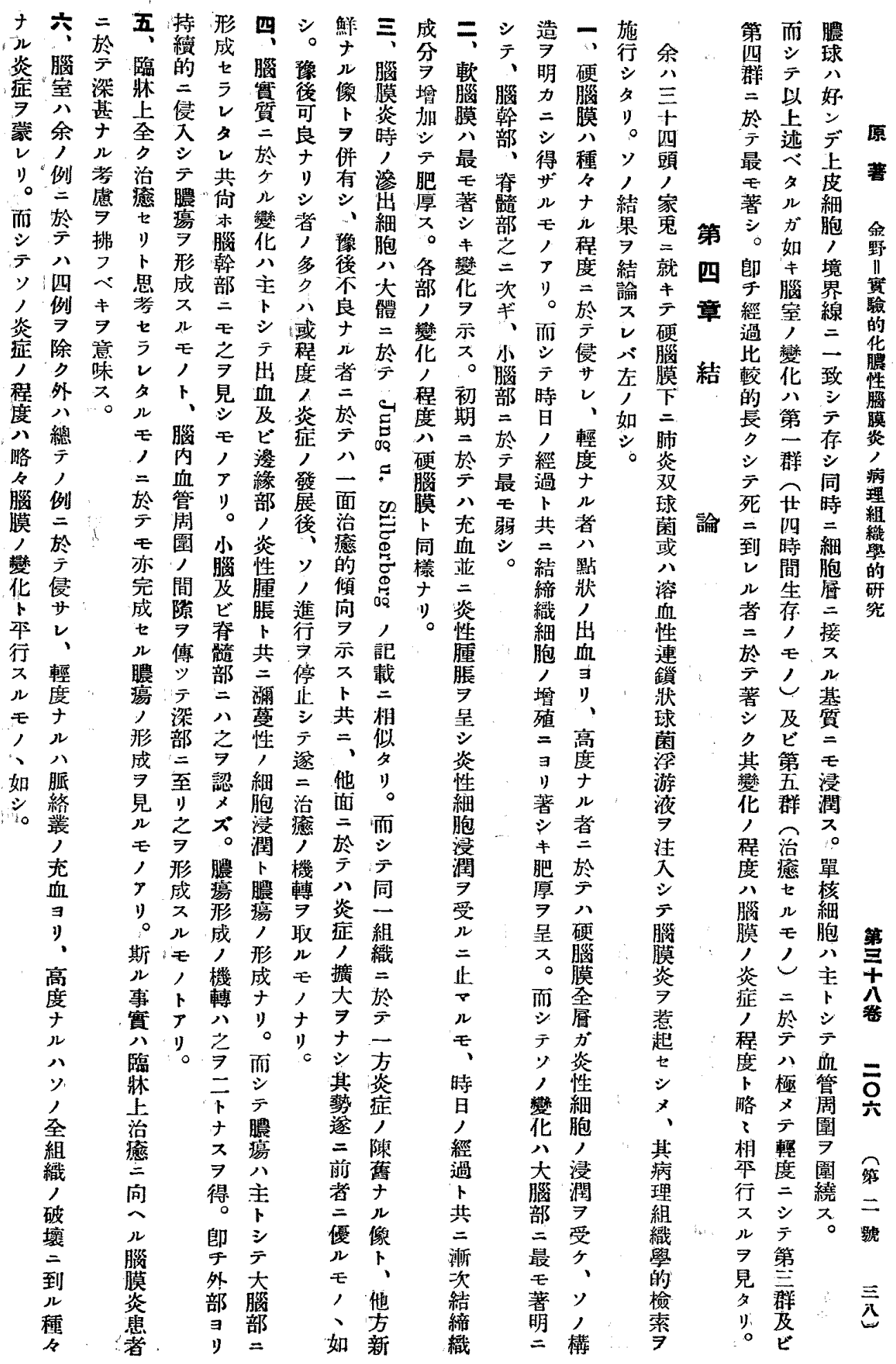




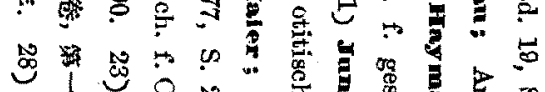

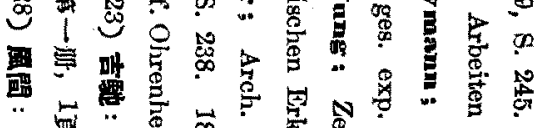

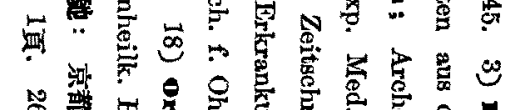

$\overline{\bar{o}}$

第

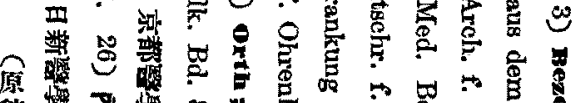

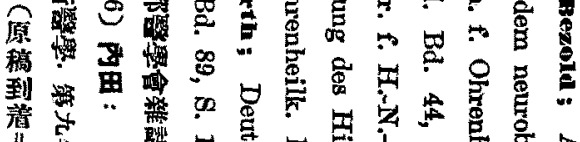




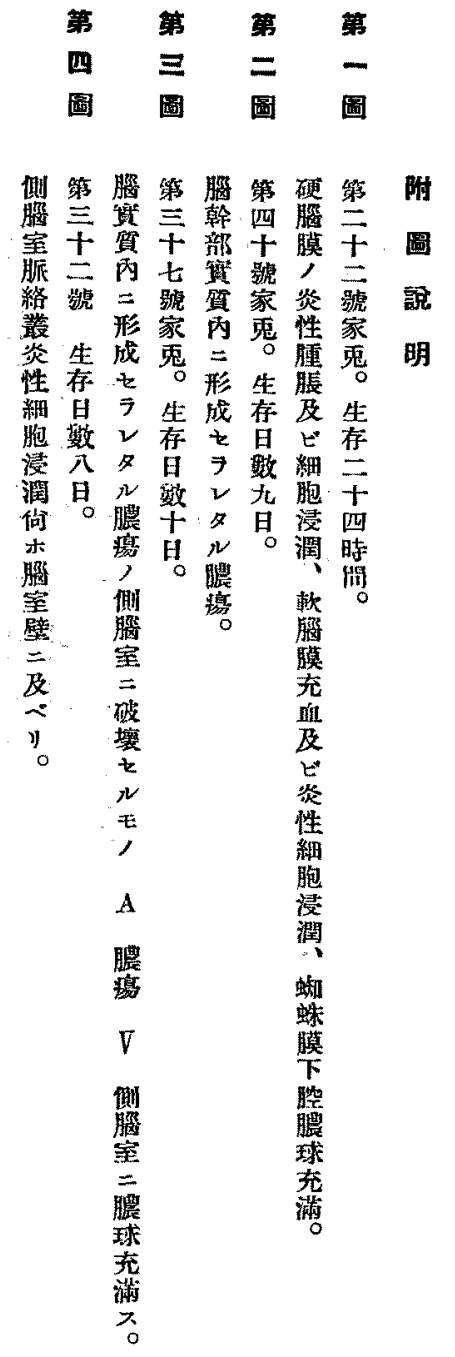

第

$\rightarrow$

嚚

回 


\section{金 野論 文 附}

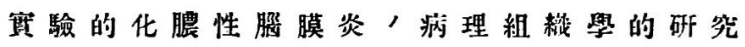

Fig. 1.

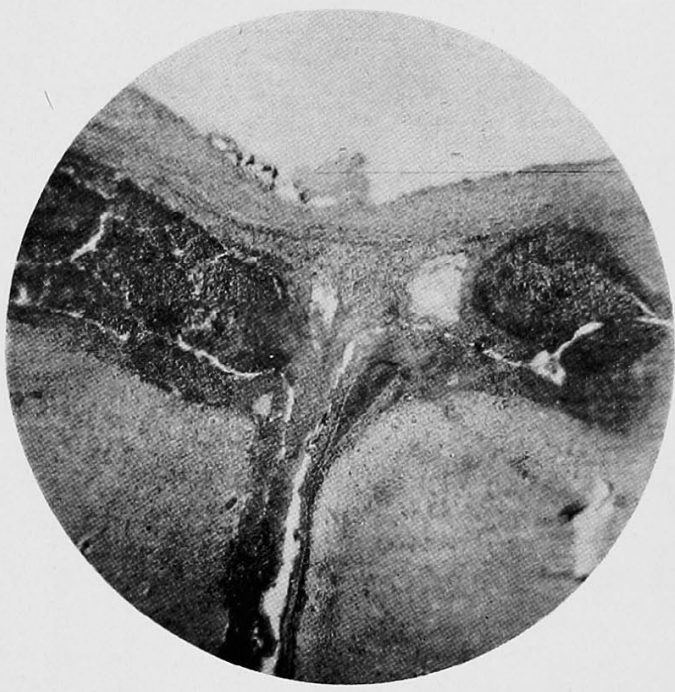

Fig. 3.

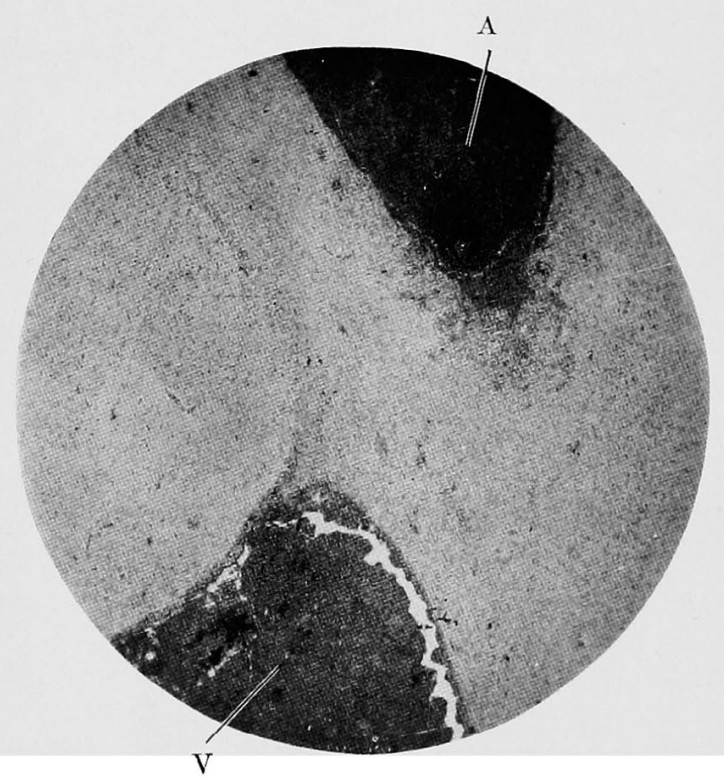

Fig. 2.

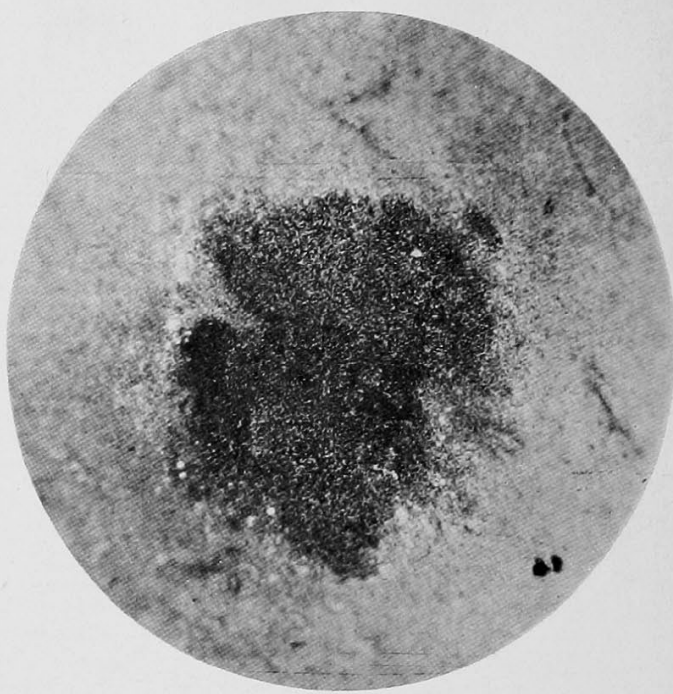

Fig. 4.

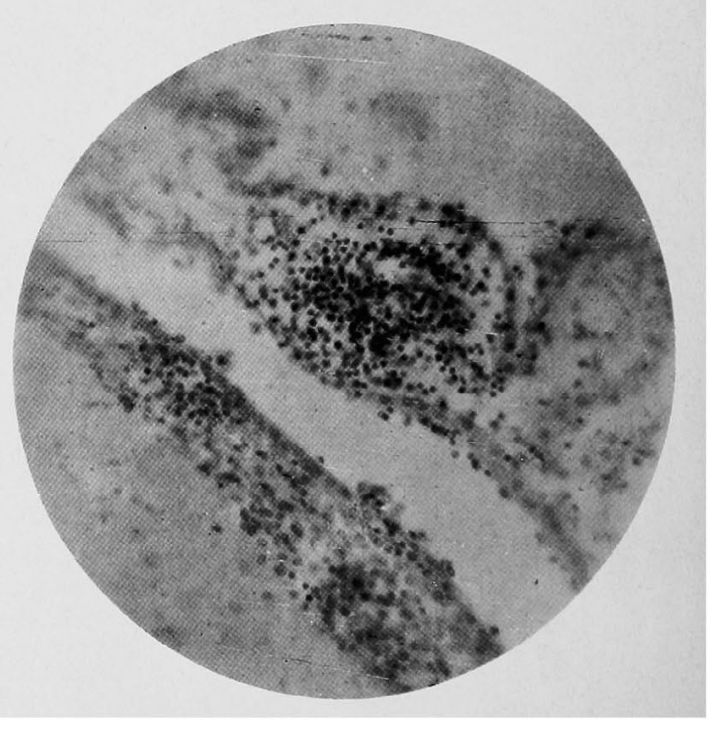

I. Fionno: Pathologisch-histologische Untersuchungen der experimentellen eitrigen Meningitis. 
V) Bei klinisch ganz geheilten Faellen kann man auch ganz ausgebildete Abszesse, finden. Also auch bei klinisch Heilungstendenz zeigenden Patienten, grosse Vorsicht. VI) Alle Ventrikel waren ausser bei 4 Faellen immer infiltriert. Der Plexus chorioideus zeigt verschiedene Veraenderungen; deren Grad meistens mit Veraenderungen der Meningen parallel läuft.

(Autoreferat.)

\section{Histological and anatomical studies on the temporal bones in Homo (Japanese).}

Part I. A study of the pneumatic system of the temporal bone.

Von

\section{Dr. 0. Shimoda.}

From the Laryngo*, Rhino-\& Otological Clinic in Nigata Medical Faculty

(Director: Prof. Dr. E. Torii).

I have studied on 30 adult crania of Japanese, in Niigata district, making series of 56 temporal bones with their neighbouring soft parts, and have investigated minutely about the conditions of the development of pneumatic cells and the fine structure in the arrested parts of pneumatisation in pyramidal apex of petrous bone, tympanic cavity, perilabyrinth, mastoid, root-zone of zygomatic arch etc.

The following results have been obtained:-

I) The four degrees of development of pneumatic cells in the tympanic roof (Tegmen tympani).

$\begin{array}{llll}\text { full grown } & \text { Pneumatisation } & 21 & \% \\ \text { moderate } & \text { pneumatisation } & 25 & \% \\ \text { under grown } & \text { pneumatisation } & \text { I I } & \% \\ \text { non } & \text { pneumatisation } & 43 & \%\end{array}$

2) Pneumatic "cells in the tympanic floor.

$\begin{array}{llll}\text { full grown } & \text { pneumatisation } & 17 & \% \\ \text { moderate } & \text { pneumatisation } & 29 & \% \\ \text { under grown } & \text { pneumatisation } & \text { I I } & \% \\ \text { non } & 43 \%\end{array}$




\title{
Pathologisch-histologische Untersuchungen zur experimentellen eitrigen Meningitis.
}

Von

\author{
Dr. I. Konno. \\ (aus der oto-rhino-laryngologischen Klinik der medizin'schen Fakultaet \\ zu Niigata. Direktor; Prof. Dr. E. Torii.)
}

Verfasser untersuchte die pathologischen Veraenderungen bei experimenteller eitriger Meningitis.

Das Untersuchungsmaterial besteht aus: 34 Hirne und Rueckenmarke von klinisch beobachteten Kaninchen. Haertung mit Formalin, Celloidineinbettung, Haematoxylineosin, Hämatoxylin-van Gieson-, und Eisenhaematoxylinfaerbung.

Das Material wird nach der Lebensdauer in 5 Gruppen eingeteilt ;- 1) Lebensdauer, 24 Stunden, 2) 3-5 Tagen, 3) 6-9 Tagen, 4) ueber to Tagen, 5) klinisch geheilt.

I) Die Veraenderung der Dura ist sehr verschieden, d.h. von punktfoermigen Blutungen bis zur strukturlosen Durchsetzung der ganzen Schicht mit Entzuendungszellen. Es kommt zu deutlicher Verdickung durch starke Bindegewebswucherung. Der Veraenderungsgrad ist am Grosshirn am staerksten, dann Hirnstamm und. Medulla oblongata, und Kleinhirn minimal.

II) Die weichen Meningen zeigen zur Gefaessinjektion im Fruehstadium, aber nachher nehmen bindegewebige Elemente wie in der Dura zu und zeigen eine starke Verdickung.

III) Die hier beobachteten pathologischen Zellen sind meistens der Beschreibung Jung und Silberberg aehnlich. Aber in einem Praeparat findet man einerseits. Befunde einer abgelaufenen, andererseits einer frischen Entzuendung. Bei prognostisch unguenstigen Faellen ueberwiegt die Tendenz der Entzuendung, dagegen. bei prognostisch guenstigen Faellen, fehlt diese, es kommt schliesslich zur Heilung. IV) Die Veraenderungen der Hirnsubstanz sind hauptsaechlich Blutung, entzuendliche Schwellung, diffuse zellige Infiltration der Hirnoserflaeche und Abszessbildung. Abszessbildung sieht man meistens im Grosshirn, dann im Hirnstamm, nicnt im Kleinhirn und Rueckenmark. Abszessbildende Prozeese sind in 2 Reihe einzuteilen, eins, von Aussen kontinuierlich fortschreitende Infiltration mit Eiterzellen, zweitens, Bildung in den tiefen Partien, entlang den perivaskulaeren Spalten der Hirngefaesse. 